

\section{Sumário}

I. Crônicas do Direito Internacional ...............................................1

REPARAÇÃo DE VÍTIMAS À LUZ DE UM TRATAdo SOBRE EMPRESAS E DIREITOS HUMANOS ............ 3 Ana Cláudia Ruy Cardia

Consumer Social Responsibility as a Requirement for Corporate Social ResponsibiliTY

Nitish Monebhurrun

Crisis in Venezuela: The Brazilian response to the massive flow of Venezuelans in

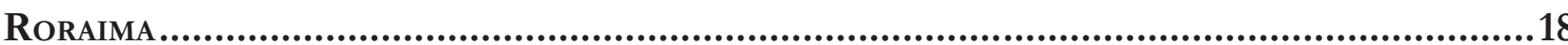

Jacqueline Salmen Raffoul

II. Dossiê EsPecial: Business and Human Rights.........................................23

Some remarks on the third sessions of the Business and Human Rights Treaty Pro-

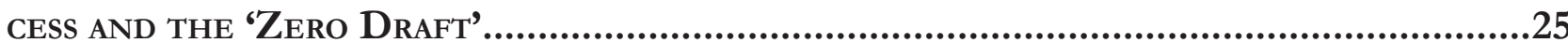

Humberto Cantú Rivera

The United Nations guiding principles on business and human Rights, the State

DUTY TO PROTECT HUMAN RIGHTS AND THE STATE-BUSINESS NEXUS.

Mihaela Maria Barnes

HARdening SOFT LAW: ARE THE EMERging Corporate SOCIAL DisClOSURE LAWS CAPABLE OF GENERATING SUBSTANTIVE COMPLIANCE WITH HUMAN RIGHTS?

Justine Nolan

Del Documento de Elementos al Draft 0: apuntes jurídicos respecto del posible CONTENIDO DEL PROYECTO DE INSTRUMENTO VINCULANTE SOBRE EMPRESAS TRANSNACIONALES

Y OTRAS EMPRESAS CON RESPECTO A LOS DERECHOS HUMANOS

Adoración Guamán 
ACCESS TO REMEDIES AND THE EMERGING ETHICAL DILEMMAS: CHANGING CONTOURS WITHIN THE BUSINESS-HUMAN RIGHTS DEBATE

Justin Jos

LA RESPONSABILIDAD PENAL DE LAS EMPRESAS POR GRAVES VIOLACIONES DE DERECHOS HUMANOS: PRÁCTICA ACTUAL Y DESAFÍOS FUTUROS 130

Daniel Iglesias Márquez

THE ENVIRONMENTAL LAW DIMENSIONS OF AN INTERNATIONAL BINDING TREATY ON BUSINESS AND HUMAN RIGHTS

Juan Gabriel Auz Vaca

Los Objetivos de Desarrollo Sostenible en Europa y su Intersección con el Marco de los Negocios y los Derechos Humanos

Paolo Davide Farah

HumAN RIGHTS AND MARKET ACCESS 203

Danielle Mendes Thame Denny

BusinesS AND HUMAN RIGHTS IN BRAZIL: EXPLORING HUMAN RIGHTS DUE DILIGENCE AND OPERATIONAL-LEVEL GRIEVANCE MECHANiSMS IN THE CASE OF KinRoss PARACATU Gold Mine...222 Mariana Aparecida Vilmondes Türke

Human Rights and eXtractive industries in Latin America: What Responsibility of CORPORATIONS AND THEIR STATES OF ORIGIN FOR HUMAN RIGHTS VIOLATIONS IN THE INTER-American Human Rights System?.

Alberto do Amaral Junior e Viviana Palacio Revello

MultinaCiOnAIS FAST FASHION E DIREITOS HUMANOS: EM BUSCA DE NOVOS PADRÕES DE RESPONSABILIZAÇÃO 255

Laura Germano Matos e João Luis Nogueira Matias

III. Artigos sobre outros temas

EFFICIENCY AND EFFICACY OF PUBLIC FOOD PROCUREMENT FROM FAMILY FARMERS FOR SCHOOL FEEDING IN BRAZIL. 271

Rozane Márcia Triches 
A relaÇão ENTRE O GRAU de INTEGRaÇÃo ECONÔMiCA E O SISTEMA DE SOLUÇÃo DE CONTROvÉRSIAS: UM ESTUdo COMPARATIVO ENTRE A UNIÃo EURopeia E O MERCOSUl.....................286

Luciane Klein Vieira e Elisa Arruda

THE RIGHTS TO MEMORY AND TRUTH IN THE INTER-AMERICAN PARADIGMS OF TRANSITIONAL JUSTICE: THE CASES OF BRAZIL AND CHILE 308

Bruno Galindo

Juliana Passos de Castro

A margem nacional de apreciação na Corte Interamericana de Direitos Humanos.325 Gilberto Schäfer, José Eduardo Aidikaitis Previdellie e Jesus Tupã Silveira Gomes

Novos Direitos FUNDAMENTAIS NO ÂMBITo DA UNASUL: ANÁLISE DAS AGENDAS DE Brasil E VENEZUELA À LUZ DO DIREITO À PAZ.

Pedro Pulzatto Peruzzo e Arthur Ciciliati Spada

A atuação do Grupo Mercado Comum frente À Criminalidade organizada transnacio-

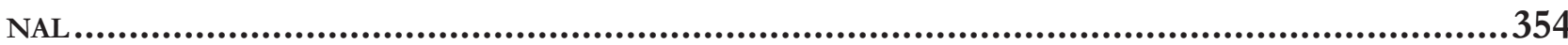

Sabrina Cunha Kesikowski, Luis Alexandre Carta Winter e Eduardo Biacchi Gomes

COUNTER-TERRORISM LEGISLATION AND TERRORIST ATTACKS: DOES HUMAN RIGHTS HAVE SPACE?

Heloisa Tenello Bretas e Daniel Damásio Borges

Territórios da ViolênCia de GÊNERo: NORMATIVA INTERNACIONAL E os Casos "CAMpo AlGodoeiro” (MÉXICO) - “Morro do Garrote” (BrasiL)

Eugênia Nogueira do Rêgo Monteiro Villa e Bruno Amaral Machado

O USO DE MECANISMOS INFORMAIS DE GOVERNANÇA GLOBAL E SUA APLICABILIDADE NAS LICITAÇÕES PÚBLICAS BRASILEIRAS.

Fabiano de Figueiredo Araujo e Paulo Afonso Cavichioli Carmona

Autonomia INSTITUCIONAL DA IGREJA CATÓliCA E A INGERÊNCIA INDEVIDA DO ESTADO BRASILEIRo POR EVENTUAIS Ilícitos CANÔNicos: ANÁlise do CASO de Formosa-GO, À luz do TraTADo Brasil-Santa SÉ de 2010 
A MORE TARGETED APPROACH TO FOREIGN DIRECT INVESTMENT: THE ESTABLISHMENT OF SCREENING SYSTEMS ON NATIONAL SECURITY GROUNDS

Carlos Esplugues Mota

IV. RESENHAS 467

Direito Internacional em Perspectiva Transcivilizacional de Yasuaki Onuma........469 Arthur Roberto Capella Giannattasio

Resenha do livro Space, Global Life: The Everyday Operation of International LaW and Development, de Luis Eslava .473

Matheus Gobbato Leichtweis

QUEM TEM MEDO DO PÓS-COLONIAL NO DIREITO INTERNACIONAL? UMA RESENHA DE "DECOLONISING INTERNATIONAL LAW: DEVELOPMENT, ECONOMIC GROWTH AND THE POLITICS OF UNIVERSAlity" de Sundhya Pahuja

Gabriel Antonio Silveira Mantelli

Direitos humanos COMO UM NOVO PROJETO PARA O Direito INTERNACIONAL? Notas sobre The Last Utopia, de Samuel Moyn .490 João Roriz 


\title{
The United Nations guiding principles on business and human rights, the State Duty to protect human rights and the State-business nexus*
}

\author{
Os princípios orientadores das Nações \\ Unidas sobre empresas e direitos humanos, \\ o dever do Estado de proteger os direitos \\ humanos e o nexo empresarial do Estado
}

Mihaela Maria Barnes **

\section{Abstract}

Despite the fact that the United Nations Guiding Principles on Business and Human Rights (UNGPs) have specific provisions that are applicable to States to ensure that businesses that are owned or controlled by the State, or that enter into transactions with the State, respect human rights; most scholarship, so far, seems to have focused mainly on the corporate responsibilities of privately owned entities to respect human rights. This article seeks to rectify this apparent gap in scholarship by providing an introduction to what the UNGPs refer to in Principles 4, 5 and 6 as 'the State-business nexus.' In this context, this article is composed of five sections and proceeds in the following manner. The first section introduces the coverage of the State-business nexus in the UNGPs. The second section seeks to determine who are the actors to whom the provisions of UNGPs 4, 5 and 6 may be applicable. The third section analyses in detail on Principles 4, 5 and 6 and shows how the UNGPs focus on this issue from three different perspectives. The fourth section examines the content of the State duty to protect human rights in the context of the State-business nexus, while the fifth section concludes.

Keywords: Human Rights. UNGPs. State-Business Nexus.

\begin{abstract}
Apesar do fato que os Princípios Orientadores das Nações Unidas sobre Empresas e Direitos Humanos (UNGPs) terem disposições específicas que são aplicáveis aos Estados para garantir que as empresas que são de propriedade ou controladas pelo Estado, ou que realizam transações com o Estado, respeitem os direitos humanos; a maioria dos estudos, até agora, parecem ter se concentrado principalmente nas responsabilidades corporativas das entidades privadas para respeitar os direitos humanos. $\mathrm{O}$ artigo procura corrigir essa aparente lacuna fornecendo uma introdução ao que os UNGPs referem nos Princípios 4, 5 e 6 como 'o nexo Estado-empresa'. Nesse contexto, esse artigo é composto de cinco seções e prossegue da seguinte
\end{abstract}

** $\mathrm{PhD}$ - International Law at the Graduate Institute of International and Development Studies Geneva.
Recebido em 29/06/2018 Aprovado em 19/07/2018 
maneira. A primeira seção introduz a cobertura do nexo Estado-empresa nos UNGPs. A segunda seção procura determinar quem são os atores para os quais as provisões dos PNGs 4, 5 e 6 podem ser aplicáveis. A terceira seção analisa em detalhes os Princípios 4, 5 e 6 e mostra como os UNGPs enfocam essa questão de três perspectivas diferentes. A quarta seção examina o conteúdo do dever do Estado de proteger os direitos humanos no contexto do nexo Estado-empresa, enquanto a quinta seção conclui.

Palavras-chave: Direitos humanos. UNGPs. Nexo EstadoEmpresa

\section{INTRODUCTION}

1. Since their endorsement in 2011 by the United Nations Human Rights Council, ${ }^{1}$ the United Nations Guiding Principles on Business and Human Rights $(\mathrm{UNGPs})^{2}$ have become the global standard concerning the protection and respect of human rights in the context of business activities, applicable to both States and corporations. ${ }^{3}$ Developed under the auspices of the United Nations (UN), by Professor John Ruggie - then Special Representative of the Secretary-General Kofi Annan on the issue of human rights and transnational corporations - the UNGPs have been generally well received by States, businesses, civil society ${ }^{4}$ as well as in academia, ${ }^{5}$ despite some criticism concerning their voluntary nature and certain other design weaknesses. ${ }^{6} \mathrm{Gi}-$

1 UNITED NATIONS. Human Rights Council. Resolution 17/4 buman rights and transnational corporations and other business enterprises, 2011. (A/HRC/RES/17/4)

2 RUGGIE, John G. Guiding principles on business and buman rights: implementing the united nations "protect, respect and remedy" framework: report of the special representative of the secretarygeneral on the issue of human rights and transnational corporations and other business enterprises. 2011. (A/HRC/17/31)

3 UNITED NATIONS. The corporate responsibility to respect human rights: an interpretative guide. 2002. (HR/PUB/12/02). p. 1.

4 BUHMANN, Karin. Navigating from "train wreck" to being "welcomed": negotiation strategies and argumentative patterns in the development of the UN framework. In. DEVA, Surya; BILCHITZ, David (Ed.). Human rights obligations of business: beyond the corporate responsibility to respect. Cambridge: Cambridge University Press, 2013.

5 BERNAZ, Nadia. Business and human rights: history, law and policy: bridging the accountability gap. Londres: Routlege, 2017. p. 195. 6 DEVA, Surya. Regulating corporate human rights violations: humanizing business. Londres: Routledge, 2014. p. 110, 112-113; SHAW, Malcolm N. International law. 7. ed. Cambridge: Cambridge Univ Press, 2014. p. 182-183. ven that the journey, which ultimately led to the endorsement of the UNGPs by the Human Rights Council, had been for a long time, characterised by confrontation and failures, ${ }^{7}$ as witnessed for instance by the lack of success of the Draft UN Code of Conduct on Transnational Corporations ${ }^{8}$ and the UN Norms on the Responsibilities of Transnational Corporations and Other Business Enterprises, ${ }^{9}$ Professor Ruggie's achievement is by all means remarkable.

2. While the development of ideologies that aimed to make business act in a responsible manner can be traced all the way back to the abolitionist movement of the Atlantic slave trade, which was later followed by attempts to develop international labour law and by the criminal prosecution of German industrialists that supported the Nazis during WWII, ${ }^{10}$ it was the UNGPs that not only finally managed to achieve a global consensus ${ }^{11}$ on this issue, but ultimately also reopened a more balanced dialogue seeking to bridge the often diverging interests of States, businesses and civil society. ${ }^{12}$ Consequently, while the UNGPs do not create any new legal obligations as such, for either States or for corporations, ${ }^{13}$ they are nevertheless a key 'soft law' ins-

7 BERNAZ, Nádia. Business and human rights: history, law and policy: bridging the accountability gap. Londres: Routlege, 2017. p. 163176; ZERK, Jennifer A. Multinationals and corporate social responsibility: limitations and opportunities in international law. First paperback edition. Cambridge: Cambridge University Press, 2011. p. 244-266.

8 UNITED NATIONS. Draft UN code of conduct on transnational corporations. [1983 Version]. Available at: <investmentpolicyhub. unctad.org/Download/TreatyFile/2891>.; SAUVANT, Karl P. The negotiations of the united nations code of conduct on transnational corporations: experience and lessons learned. The Journal of World Investment and Trade, v. 16, p. 11-87, 2015. p. 11.

9 UNIVERSITY OF MINNESOTA. Human Rights Library. Norms on the responsibilities of transnational corporations and other business enterprises with regard to human rights: E/CN.4/Sub.2/2003/12/Rev.2. 2003.

10 BERNAZ, Nádia. Business and human rights: history, law and policy: bridging the accountability gap. Londres: Routlege, 2017. p. 17-79.

11 DEVA, Surya. Treating human rights lightly: a critique of the consensus rhetoric and the language employed by the guiding principles: human rights obligations of business: beyond the corporate responsibility to respect. Cambridge: Cambridge University Press, 2013. This book chapter adopts a critical perspective on the widely accepted 'consensus rhetoric' that is believed to underpin the UNGPs. 12 DEVA, Surya. Treating buman rights lightly: a critique of the consensus rhetoric and the language employed by the guiding principles: human rights obligations of business: beyond the corporate responsibility to respect. Cambridge: Cambridge University Press, 2013. (n. 6). p. 105.

13 SHAW, Malcolm N. International law. 7. ed. Cambridge: Cambridge Univ Press, 2014. p. 182-183. (n. 6) ('These Principles Conse 
trument, which is likely to influence in a positive way ${ }^{14}$ the conduct of both States and businesses, as far the integration of human rights considerations within the ambit their economic activities is concerned. For example, the UNGPs have prompted the update of other soft law instruments such as the OECD Guidelines for Multinational Enterprises ${ }^{15}$ and the ILO Tripartite Declaration concerning Multinational Enterprises, ${ }^{16}$ which have both integrated the UNGPs in their texts. The basic architecture of the UNGPs is composed of three Pillars and 31 Principles. Pillar I contains Principles 1 to 10 and focuses on the State duty to protect human rights. Pillar II, Principles 11 to 24, deal with the corporate responsibility to respect human rights. Lastly, Pillar III Principles 25 to 31 address both States and corporations, and clarify that, while it is principally States that have an obligation to ensure that victims of human rights abuses have access to appropriate remedies, through State-based judicial and non-judicial mechanis$\mathrm{ms}$, businesses are also encouraged to create effective operational-level grievance mechanisms. ${ }^{17}$

3. With this general background in mind, it is worthy of note that, bar a few notable and valuable exceptions, ${ }^{18}$

international legal obligations as such...The realm is that of "soft law", of expectations, of anticipation not of binding international (as opposed to national) legal regulation.')

14 SHELTON, Dinah L. 'Soft law', handbook of international law. Routledge Press, 2008. Available at: <http://papers.ssrn.com/ sol3/papers.cfm?abstract_id $=1003387>$. ("Non-binding norms or informal social norms can be effective and offer a flexible and efficient way to order responses to common problems. They are not law and they do not need to be in order to influence conduct in the desired manner.')

15 OECD guidelines for multinational enterprises: 2011 edition. Paris: OECD Publishing, 2011. p. 31-34.

16 INTERNATIONAL LABOUR ORGANIZATION. Tripartite declaration of principles concerning multinational enterprises and social policy: adopted by the Governing Body of the International Labour Office at its 204th Session (Geneva, November 1977) and amended at its 279th (November 2000), 295th (March 2006) and 329th (March 2017) Sessions). Geneva: ILO, 2017. p. 3-5.

17 RUGGIE, John G. Guiding principles on business and buman rights: implementing the united nations "protect, respect and remedy" framework: report of the special representative of the secretarygeneral on the issue of human rights and transnational corporations and other business enterprises. 2011. (A/HRC/17/31). (n. 2). p. 2526. Principles 29 and 30.

18 BACKER, Larry Catá. The human rights obligations of State Owned Enterprises (SOEs): emerging conceptual structures and principles in national and international law and policy. Vanderbilt Journal of Transnational Law, v. 51, 2017. Available at: <https://papers.ssrn.com/sol3/papers.cfm?abstract_id=2980533>.; BACKER, Larry Catá. Between state, company, and market: a preliminary engagement on the business and human rights obligations of states and State Owned Enterprises (SOEs). Available at: < https://ssrn.com/ scholarship so far seems to have concentrated largely on the role that privately-owned transnational corporations may have had in the creation of certain 'governance gaps' ${ }^{19}$ other types of non-State actors are recently becoming increasingly important in a globalised world. ${ }^{20}$ In this context, Professor Ruggie noted in 2006, barely a year after his appointment that:

[W]ays must be found to engage State-owned enterprises in addressing human rights challenges in their spheres of operation. They are becoming increasingly important players in some of the most troubling industry sectors yet appear to operate beyond many of the external sources of scrutiny to which commercial firms are subject. ${ }^{21}$

4. As the mandate of the Special Representative advanced on the topic of business and human rights generally, so did the coverage of State ownership. For example, later reports continued to make references to the challenges associated with the human rights dimension of State ownership and suggested ways how those challenges could be tackled. ${ }^{22}$ The importance of this

abstract=2869944>.; RAJAVUORI, Mikko. State ownership and the united nations business and human rights agenda: three instruments, three narratives. Indiana Journal of Global Legal Studies, v. 23, n. 2, summer, 2016. p. 665.

19 SIMONS, Penelope; MACKLIN Audrey. The governance gap: extractive industries, human rights, and the home state advantage. London: Routledge, 2014. p. 9-21; Zerk (n 7); CLAPHAM, Andrew. Human rights obligations of non-state actors. Oxford: OUP Oxford, 2006. p. 195-266.

20 UNITED NATIONS. World investment report 2014: investing in the SDGs: an action plan. 2014. p. ix; UNITED NATIONS. World investment report 2017: investment and the digital economy. 2017. p. 30. For example, UNCTAD estimates that there are approximately 1,500 State-owned multinational enterprises that operated outside their home State and which had a network of more than 86,000 affiliates. Furthermore, it should also be noted that sovereign foreign direct investment accounted for over $11 \%$ of the total global foreign direct investment in 2014. This figure does not however, include investments made by sovereign wealth funds, whose assets under management have reached close to USD 7.5trillion as of 2018. For further information on this see the 2014 UNCTAD World Investment Report quoted above at page 30.

21 John Ruggie, 'Promotion and Protection of Human Rights (Interim Report of the Special Representative of the Secretary-General on the Issue of Human Rights and Transnational Corporations and Other Business Enterprises)' (2006) E/CN.4/2006/97 20.

22 RUGGIE, John G. State responsibilities to regulate and adjudicate corporate activities under the united nations core human rights treaties: an overview of treaty body commentaries: report of the special representative of the secretary-general on the issue of human rights and transnational corporations and other business enterprises. Kennedy School of Government; Harvard Law Schooll, 2007. (A/ HRC/4/35/Add.1). p. 32-33; John Gerard Ruggie, 'State Responsibilities to Regulate and Adjudicate Corporate Activities under the United Nations' Core Human Rights Treaties (Report of the Special Representative of the Secretary-General on the Issue of Human 
issue was underlined, for instance, when it was noted that, by virtue of the connection between the State and its businesses, States may be held responsible for the acts of those entities, either under the duty to respect, if State-owned entities are to be considered as State organs or agents, or under the duty to protect, if Sate-owned entities are treated on par with private businesses. ${ }^{23}$ Ultimately, specific provisions on the State-business nexus were included in UNGPS 4, 5 and 6, as Section 3 of this article analyses below.

5. Nevertheless, as some recent reports of the UN Working Group on Business and Human Rights (UN Working Group) have shown, while in some circumstances significant progress has been made by States as

Rights and Transnational Corporations and Other Business Enterprises)' (John F Kennedy School of Government 2007) paras 10, 78-80; RUGGIE, John G. Corporations and human rights: a survey of the scope and patterns of alleged corporate-related human rights abuse: report of the special representative of the secretary-general on the issue of human rights and transnational corporations and other business enterprises. 2008. (A/HRC/8/5/Add.2). p. 9.; RUGGIE, John G. Protect, respect and remedy: a framework for business and human rights: report of the special representative of the secretarygeneral on the issue of human rights and transnational corporations and other business enterprises, John Ruggie. 2008. (A/HRC/8/5). p. 10-11, 25; RUGGIE, John G. Summary of five multi-stakeholder consultations: report of the special representative of the secretarygeneral on the issue of human rights and transnational corporations and other business enterprises. 2008. (A/HRC/8/5/Add.1). p. 23; RUGGIE, John G. State obligations to provide access to remedy for human rights abuses by third parties, including business: an overview of international and regional provisions, commentary and decisions (report of the special representative of the secretary-general on the issue of human rights and transnational corporations and other business enterprises. 2009. (A/HRC/11/13/Add.1). p. 33.; RUGGIE, John G. Business and buman rights: further steps toward the operationalization of the "protect, respect and remedy" framework: report of the special representative of the secretary- general on the issue of human rights and transnational corporations and other business enterprises. 2010. (A/HRC/14/27). p. 7-8; RUGGIE, John G. Guiding principles on business and buman rights: implementing the united nations "protect, respect and remedy" framework: report of the special representative of the secretary-general on the issue of human rights and transnational corporations and other business enterprises. (n. 2). p. 9-10; RUGGIE, John G. Human rights and corporate law: trends and observations from a crossnational study conducted by the special representative: report of the special representative of the secretarygeneral on the issue of human rights and transnational corporations and other business enterprises. 2011. (A/HRC/17/31/Add.2). p. 26, 30, 33, 40-41.

23 RUGGIE, John G. State responsibilities to regulate and adjudicate corporate activities under the united nations core human rights treaties: an overview of treaty body commentaries: report of the special representative of the secretary-general on the issue of human rights and transnational corporations and other business enterprises. Kennedy School of Government; Harvard Law Schooll, 2007. (A/ HRC/4/35/Add.1). (n. 22). p. 33. far as the State-business nexus is concerned, ${ }^{24}$ in other circumstances State officials were not even aware that the UNGPs applied to entities that are owned or controlled by the State. ${ }^{25}$ This issue has been succinctly summarised by Dante Pesce, Chair of the UN Working Group in the following manner:

Governments are currently sending an incoherent message to businesses. On the one hand, they ask private businesses to respect human rights, and increasingly set out such expectations in law and policy, on the other hand - barring notable exceptions - they show no great desire to use the means at their disposal to ensure that those enterprises they own or control respect human rights. It is high time for States to show concrete leadership, and require the enterprises they own or control to be role models on human rights. Doing so is part of States' international legal obligations, and it will only reinforce the legitimacy of States' expectations towards private businesses. Yet these human rights impacts - and the duties of States to protect against them - remain largely ignored.

6. The lack of clear guidance concerning the application of the UNGPs to State-owned entities was also noted. ${ }^{26}$ Furthermore, the UN Working Group has also recently issued recommendations to the G20 Group of States on how to ensure and advance sustainable supply chains, making specific reference to the role that States, as economic actors in their own right, have to play in this context. Of particular importance is the fact that

24 UNITED NATIONS. Human Rights Concil. Promotion and protection of all human rights, civil, political, economic, social and cultural rights, including the right to development: report of the working group on the issue of human rights and transnational corporations and other business enterprises on its mission to Brsail: note by the secretariat. 2016. (A/HRC/32/45/Add.1). p. 6; UNITED NATIONS. Human Rights Concil. Promotion and protection of all human rights, civil, political, economic, social and cultural rights, including the right to development: report of the working group on the issue of human rights and transnational corporations and other business enterprises on its visit to the Republic of Korea. 2017. (A/HRC/35/32/Add.1). p. 10-12.

25 UNITED NATIONS. Human Rights Concil. Promotion and protection of all human rights, civil, political, economic, social and cultural rights, including the right to development: report of the working group on the issue of human rights and transnational corporations and other business enterprises on its visit to the Republic of Korea. 2017. (A/ HRC/35/32/Add.1). p. 5.

26 'State-Owned Enterprises Must Be "Role Model" in Respecting Human Rights - UN Report' (UN News, 17 June 2016) < https://news.un.org/en/story/2016/06/532442-state-owned-enterprises-must-be-role-model-respecting-human-rights-un-report $>$.; UNITED NATIONS. Human Rights Concil. Promotion and protection of all buman rights, civil, political, economic, social and cultural rights, including the right to development: report of the working group on the issue of human rights and transnational corporations and other business enterprises. 2016. (A/HRC/32/45). p. 51, 87, 98, 101. 
the UN Working Group has noted that 'the current lack of attention paid to the human rights impact and the responsibilities' of entities that are connected with the State and 'the duty of Governments that own or control them' in this area is 'striking. ${ }^{27}$ This has prompted the UN Working Group to issue a report with specific recommendations to States about how to integrate the UNGPs in the activities and operations of entities that are owned and controlled by the State. ${ }^{28}$ The contents of this report will be examined in in Sections 3 and 4 of this Article, which deal in detail with the content State-business nexus under the UNGPs. However, firstly it is required to determine which actors might fall within the ambit of the State-business nexus.

\section{WHO ARE THE ACTORS THAT FALL WITHIN THE AMBIT OF THE UNGPS STATE-BUSINESS NEXUS?}

7. When performing research on State ownership and the role of the State as an economic actor, one may encounter myriad different definitions and terminologies such as 'sovereign wealth funds', 'government company', 'national oil company', 'state trading company', 'canalizing agencies', 'export credit agencies', 'State-owned multinational enterprise', 'official investment insurance or guarantee agencies', 'development agencies', 'development finance institutions', etc. Even the term 'state-owned enterprise' is considered as providing only 'an approximate description of the complexity of forms and organisations that State companies may assume' and which have reached 'an apogee of fantasy and ingenuity in terminology and legal forms. ${ }^{29}$ For example, State-owned multinational enterprises have been defined by UNCTAD as 'separate legal entities established or acquired by governments to engage in commercial activities, including FDI operations, by way of having affiliates abroad or engaging in non-equity

27 INSTITUTE FOR HUMAN RIGHTS AND BUSINESS (IHRB). Letter to the Members of the G20 Employment Working Group. 24 mar. 2017. p. 6.

28 Leading by Example: The State, State-Owned Enterprises and Human Rights (UNITED NATIONS. General Assembly. Human Right Council. Leading by example: the state, state-owned enterprises and human rights: report of the working group on the issue of human rights and transnational corporations and other business enterprises. 2016. (A/HRC/32/45)

29 TONINELLI, Pierangelo Maria. The rise and fall of state-owned enterprise in the western world. Cambridge: Cambridge University Press, 2000. p. 4-5. modes' and in which the government has at least a 10 percent ownership share. ${ }^{30}$ Sovereign wealth funds are 'funds established, owned and controlled by local or central governments', and which acquire 'equity interests in companies listed in international markets, operating in sectors considered as strategic by their country of incorporation. ${ }^{31}$ Sovereign wealth funds are some of the largest and most important economic actors that exist today ${ }^{32}$ and they have played a key role in the stabilisation of the markets during the 2007 financial crisis. ${ }^{33}$ Export credit agencies are 'publicly funded and government-owned "institutions that support and subsidize national trade and investment activities, particularly in developing and emerging markets." ${ }^{34}$ National oil companies are also extremely important economic actors in this context, since they own and control the world energy supply, ${ }^{35}$ and their activities are not necessarily limited to operations within national borders. ${ }^{36}$

8. Despite their varied terminology, and the fact that some of those entities engage in economic activities directly, as State-owned enterprises and national oil companies do, while others are only passive investors

30 UNITED NATIONS. World investment report 2017: investment and the digital economy. 2017. (n. 20). p. 30.

31 BASSAN, Fabio. The law of sovereign wealth funds. Edward Elgar, 2011. p. 32.

32 SOVEREIGN wealth fund rankings: SWFI: Sovereign Wealth Fund Institute. Available at: <https://www.swfinstitute.org/sovereign-wealth-fund-rankings/>. For example, as of 20 June 2018, the assets under the management of sovereign wealth funds has reached USD 7,861.65 trillion.

33 BACKER, Larry Catá. Sovereign investing in times of crisis: global regulation of sovereign wealth funds, state owned enterprises and the chinese experience. Transnational Law \& Contemporary Problems, v. 19, n. 1, 2009. p. 4, 15.

34 CAN, Özgür; SECK, Sara L. The legal obligations with respect to buman rights and export credit agencies: final legal discussion paper: july 2006. Ottawa: Halifax Intiative Coalition, 2006. p. 23. Available at: $<$ http://www.halifaxinitiative.org/content/legal-obligations-respect-human-rights-and-export-credit-agencies-june-23-2006>. Accessed: 20 jun. 2018; GIANTURCO, Delio E. Export credit agencies: the unsung giants of international trade and finance. Santa Barbára: Greenwood Publishing Group, 2001. p. 1.

35 HULTS, David R.; VICTOR, David G.; THURBER, Mark (Ed.). Oil and governance: state-owned enterprises and the world energy supply. Cambridge: Cambridge University Press, 2012. p. 3.

36 NATIONAL oil companies: beyond boundaries, beyond borders: an emerging class of multinational oil companies is changing the competitive landscape. Available at: <http://www.bain.com/ publications/articles/national-oil-companies-beyond-boundaries. aspx>.; Mohammed Aly Sergie, 'Qatar Petroleum Expanding Overseas With Focus on Production' (Bloomberg.com) <http://www. bloomberg.com/news/articles/2015-06-23/qatar-petroleum-eyesforeign-expansion-after-restructuring >. Accessed: 7 Nov. 2015. 
in other entities, as is the case for sovereign wealth funds and export credit agencies, all those entities share a common characteristic: a sovereign State owns them. From the perspective of the UNGPs this is an important issue given that initially Professor Ruggie only referred to 'State-owned enterprises', in his first report that included references to what would ultimately become Principles 4, 5 and 6 of the State-business nexus. ${ }^{37}$ Based on this, could it be the case that the UNGPs only apply to State-owned enterprises, thus excluding from its sphere of applications any other entities that are State-owned, such as sovereign wealth funds or export credit agencies? While a recent report prepared by the UN Working Group focuses mainly on State-owned enterprises, it also notes that sovereign wealth funds, export credit agencies and other similar entities can have the potential to impact human rights. ${ }^{38}$ Furthermore, Principle 4 of the UNGPs refers to 'business enterprises that are owned or controlled by the State or that receive substantial support and services from State agencies such as export credit agencies and official investment insurance or guarantee agencies.' The Commentary to the UNGPs further clarifies that the UNGPs are applicable to 'business enterprises controlled by the State' and also to 'a range of agencies linked formally or informally to the State' and which 'may provide support and services to business activities. ${ }^{39}$ Consequently, this means that the UNGPs would apply to all entities that are owned and controlled by the State, regardless of the formal way in which those entities are legally structured. As such, for the remainder of this article, all entities that are owned or controlled by the State, will be simply referred as State-owned entities (SOEs). This approach thus seeks to overcome, what certain leading scholars have called the

37 RUGGIE, John G. Promotion and protection of buman rights: interim report of the special representative of the secretary-general on the issue of human rights and transnational corporations and other business enterprises. 2006. (E/CN.4/2006/97). p. 20.

38 Leading by Example: The State, State-Owned Enterprises and Human Rights (UNITED NATIONS. Human Rights Concil. Promotion and protection of all human rights, civil, political, economic, social and cultural rights, including the right to development: report of the working group on the issue of human rights and transnational corporations and other business enterprises. 2016. (A/HRC/32/45)' (n. 28) p. 6-7.

39 RUGGIE, John G. Guiding principles on business and buman rights: implementing the united nations "protect, respect and remedy" framework: report of the special representative of the secretarygeneral on the issue of human rights and transnational corporations and other business enterprises. (n. 2). p. 9. 'mania for compartimentalisation', ${ }^{40}$ that is encountered when one deals with the regulation of State ownership, despite the fact that such 'compartimentalisation' can only be justified for 'static purposes. ${ }^{41}$

9. This makes sense, because the State, as an economic actor, should be a model corporate citizen, regardless of the way in which the entity, though which the State conducts the economic activity in that particular case, is ultimately structured from a legal point of view. To be sure, there will be differences in how the UNGPs would be implemented in the operations of sovereign wealth funds (since these entities operate principally as passive investors), when compared to the implementation of the UNGPs in the activities of a State-owned enterprise. For example, State-owned enterprises could have on-the-ground operations in conflict-affected areas and Principle 7 of the UNGPs specifically addresses the risk of gross human rights abuses in this situation, by requiring engagement with the business enterprises from 'the earliest stage possible. ${ }^{42}$

\section{Three Perspectives on the UNGPs and the State-business nexus}

10. The UNGPs offer three perspectives on the State-business nexus in Pillar I; Principles 4, 5 and 6, under the State duty to protect human rights. The first perspective is that covered by Principle 4 of the UNGPs and which states that:

States should take additional steps to protect against human rights abuses by business enterprises that are owned or controlled by the State, or that receive substantial support and services from State agencies such as export credit agencies and official investment insurance or guarantee agencies, including, where appropriate, by requiring human rights due diligence. ${ }^{43}$

40 BACKER, Larry Catá. The human rights obligations of State Owned Enterprises (SOEs): emerging conceptual structures and principles in national and international law and policy. Vanderbilt Journal of Transnational Law, v. 51, 2017. Available at: <https://papers.ssrn.com/sol3/papers.cfm?abstract_id=2980533 >. p. 12.

41 BOLTON, Patrick; SAMAMA, Frederic; STIGLITZ, Joseph E. (Ed.). Sovereign wealth funds and long-term investing. New York: Columbia University Press, 2012. p. 210.

42 BACKER, Larry Catá. Corporate social responsibility in weak governance zones. Santa Clara J. Int'l L. v. 14, n. 297, p. 297-323, 2016. Available at: <http://digitalcommons.law.scu.edu/scujil/ vol14/iss1/10>. See in this context also Principle 7 of the UNGPs. 43 RUGGIE, John G. Guiding principles on business and buman rights: implementing the united nations "protect, respect and remedy" 
11. Consequently, Principle 4 of the UNGPs addresses the State ownership function directly as well as indirectly. The role of the direct State ownership function is evidenced by the first half of Principle 4, which provides that States must take 'additional steps to protect against human rights abuses' by all businesses that have a connection with the State, either by virtue of the fact that the State owns that business, or in circumstances where the State controls that entity. The focus on ownership and control means that the approach taken by the UNGPs in this context is broad and - to a certain extent - mirrors the rules of State responsibility found in general international law, as codified by the ILC Articles, ${ }^{44}$ as discussed further below. For example, the fact that States may be held responsible for human rights violations that have been perpetrated by entities that engage in business activities on behalf of the State, is well established and undisputed, as among others, the jurisprudence of the European Court of Human Rights shows. ${ }^{45}$ Nevertheless, State responsibility does not operate automatically and just because an entity is owned by a State, it does not mean that a State is directly responsible for the acts of those entities in all circumstances. For State responsibility to arise three elements must be satisfied. Firstly, there must be an internationally wrongful act or omission. Secondly, that act or omission must constitute a breach of an international obligation of the State in question. Thirdly, the international wrongful act must be attributable to the State under the international law rules of State responsibility, as codified by the ILC Articles. As far as the first element is concerned, Article 1 of the ILC Articles states that 'every international wrongful act entails the international responsibility of that State.' In this context, the net is cast wide and State responsibility could arise for any acts or omissions that may be contrary to the obligations of that State under international law, including human rights violations. ${ }^{46}$ The second element is satisfied if a breach of an internatio-

framework: report of the special representative of the secretarygeneral on the issue of human rights and transnational corporations and other business enterprises. (Emphasis added.). p. 9.

44 DRAFT articles on responsibility of states for internationally wrongful acts. 2001.

45 CASE of Heinisch v Germany. ECtHR, 2008. (Application n. 28274/08, Judgment 21 July 2011); CASE of Fadeyeva v Russia. ECHR, 2005. (Application n. 55723/00, 9 June 2005); CASE of Dubetska \& ors v Ukraine. ECHR, 2003. (Application n. 30499/03); CASE of Yershova v Russia. ECHR, 2004. (Application n. 1387/04, 8 April 2010)

46 CRAWFORD, James. State responsibility: the general part. Cambridge: Cambridge Univ. Press, 2014. (1. Paperback ed.). p. 219-220. nal obligation occurs in that case. Article 12 of the ILC Articles states that a breach is an 'act or omission' which is not in conformity with what is required of it by that obligation. ${ }^{47}$

12. As far as attribution is concerned - and thus the satisfaction of the third element - the ILC Articles have specific provisions that deal with attribution in Articles 4, 5 and $8 .{ }^{48}$ Under Article 4 of the ILC Articles, attribution is based on the status of an entity as a State organ. In this circumstance, if a SOE is given the status of a State organ under the domestic law of a given State, ${ }^{49}$ or is found to act as a de facto State organ, ${ }^{50}$ all the acts of that entity will be automatically attributable to the State, without any further inquiry, by virtue of the operation of the principle of the unity of the State, all the acts of the various organs, agencies and instrumentalities are considered to be ultimately those of the State in question. ${ }^{51}$ However, it should also be recalled that under the ILC rules of State responsibility, mere ownership alone by the State of a SOE is not sufficient to attribute the acts of that entity to the State in question or to make it a State organ ${ }^{52}$ because, in international law, separate legal

47 UNITED NATIONS. International Law Commission. Draft articles on responsibility of states for internationally wrongful acts, with commentaries. 2008. Available at: <http://legal.un.org/ilc/texts/instruments/english/commentaries/9_6_2001.pdf>. p. 55. (The phrase "not in conformity with" is flexible enough to cover the many different ways in which an obligation can be expressed, as well as the various forms which a breach may take.')

48 DRAFT articles on responsibility of states for internationally wrongful acts. 2001. (n. 44); UNITED NATIONS. International Law Commission. Draft articles on responsibility of states for internationally wrongful acts, with commentaries. 2008. Available at: <http://legal. un.org/ilc/texts/instruments/english/commentaries/9_6_2001. pdf>. p. 38-49.

49 UNITED NATIONS. International Law Commission. Draft articles on responsibility of states for internationally wrongful acts, with commentaries. 2008. Available at: <http://legal.un.org/ilc/texts/instruments/english/commentaries/9_6_2001.pdf>. p. 42. The Commentary clarifies that the term 'person or entity' is used in the broadest sense to include 'any person or entity.'

50 UNITED NATIONS. International Law Commission. Draft articles on responsibility of states for internationally wrongful acts, with commentaries. 2008. Available at: <http://legal.un.org/ilc/texts/instruments/english/commentaries/9_6_2001.pdf>. ('The State 'cannot avoid responsibility for the conduct of a body which does in truth act as one of its organs merely by denying it that status under its own law [and consequently, each case will have to be dealt with on the basis of its own facts and circumstances.')

51 UNITED NATIONS. International Law Commission. Draft articles on responsibility of states for internationally wrongful acts, with commentaries. 2008. Available at: <http://legal.un.org/ilc/texts/instruments/english/commentaries/9_6_2001.pdf>. p. 35.

52 Jaemin Lee, 'State Responsibility and Government-Affiliated Entities in International Economic Law: The Danger of Blurring 
personality is generally observed, bar a finding of fraud or other malfeasance..$^{53}$ Consequently, with the focus in the UNGPs being on ownership and control Principle 4 would apply to all SOEs that are owned by the State. This ultimately means that States would have to ensure they take 'additional steps to protect against human rights abuses' in all circumstances, including in cases where the State is merely a shareholder and does not actually exercise any control over the business in question.

13. Attribution under Article 5 is based not on status, but on the exercise of governmental authority. Under Article 5 what is important is the exercise of governmental authority in that particular instance. Given that States can delegate the performance of certain activities that ultimately involve the exercise of governmental authority - such as policing and the maintenance of security and which are increasingly being performed by private entities - it was felt that States 'should not be able to evade their responsibility' as a matter of international law, by delegating those functions to privately-owned entities. ${ }^{54}$ Consequently, under Article 5 of the ILC Articles, States can be responsible for the acts or omissions of fully private, as well as State-owned entities, as long as in that particular instance, there was an exercise of governmental authority. The provisions of Article 5 of the ILC are thus mirrored by Principle 5 of the UNGPs which, as discussed below, was designed to ensure that States exercise adequate oversight over all manner of entities (including private entities) that may be exercising elements of governmental authority, in cases where, for instance, previously State-owned businesses and functions associated with the State, such as the provision of basic services, have been privatised.

14. Under Article 8 of the ILC Articles, and which is likely to cover most SOEs, States are responsible for the acts or omissions of the entities that are under the

the Chinese Wall between 'State Organ'and 'Non-State Organ'as Designed in the ILC Draft Articles' (2015) 49 Journal of World Trade 117, 117.

LEE, Jaemin. State responsibility and government-affiliated entities in international economic law: the danger of blurring the chinese wall between 'state organ'and 'non-state organ'as designed in the ilc draft articles. Journal of World Trade, v. 49, Issue 1, 2015. p. 117.

53 CASE Concerning Barcelona Traction, Light and Power Company, Limited: Belgium v Spain. Judgment, ICJ Reports 1970. p. 3. [56].

54 UNITED NATIONS. International Law Commission. Draft articles on responsibility of states for internationally wrongful acts, with commentaries. 2008. Available at: <http://legal.un.org/ilc/texts/instruments/english/commentaries/9_6_2001.pdf>. p. 42. direction and control of the State thus reflecting the element of control present in Principle 4 of the UNGPs. While the tests for attribution of acts or omissions that may fall under the scope of Article 8 of the ILC is based on 'effective control' being exercised over the entity in question - and which as indicated in jurisprudence is exceedingly onerous ${ }^{55}$ - some scholars have noted that a lower standard of control may be required under international human rights law. ${ }^{56}$ For example Leo R. Hertzberg, Ulf Mansson, Astrid Nikula and Marko and Tuovi $v$ Finland was a case heard by the Human Rights Committee under Article 19 of the International Covenant on Civil and Political Rights (ICCPR) (freedom of expression), Articles 1 (right of the to receive communications from a State party) and Article 2 (exhaustion of domestic remedies) of the Optional Protocol of the ICCPR. ${ }^{57}$ The authors of the Communication complained that the Finnish authorities, including organs of the State-owned and controlled Finnish Broadcasting Company, interfered with their right to freedom of expression by imposing sanctions or censoring participants in radio and TV programmes that dealt with homosexua-

55 INTERNATIONAL COURT OF JUSTICE. Military and paramilitary activities in and against Nicaragua: Nicaragua $\mathrm{v}$ United States of America. Merits, Judgment ICJ Reports 1986. p. 14. [116]; APPLICATION of the International Convention on the Elimination of All Forms of Racial Discrimination: Georgia v Russian Federation. Provisional Measures (No 2008/35). 15 oct. 2008. [400]. (For example, in Nicaragua, the International Court of Justice said that: The Court has taken the view ... that United States participation, even if preponderant or decisive, in the financing, organizing, training, supplying and equipping of the contras, the selection of its military or paramilitary targets, and the planning of the whole of its operation, is still insufficient in itself, on the basis of the evidence in the possession of the Court, for the purpose of attributing to the United States the acts committed by the contras in the course of their military or paramilitary operations in Nicaragua. All the forms of United States participation mentioned above, and even the general control by the respondent State over a force with a high degree of dependency on it, would not in themselves mean, without further evidence, that the United States directed or enforced the perpetration of the acts contrary to human rights and humanitarian law alleged by the applicant State. Such acts could well be committed by members of the contras without the control of the United States. For this conduct to give rise to legal responsibility of the United States, it would in principle have to be proved that that State had effective control of the military or paramilitary operations of which the alleged violations were committed.')

56 MCCORQUODALE, Robert. The impact of international human rights law on state responsibility. In: KAMMINGA, Menno; SCHEININ, M. (Ed.). The impact of human rights on general international law. Oxford: Oxford University Press, 2009. p. 235-254.

57 HERTZBERG, Leo et al. V. Finland: communication n. 61/1979, UN Doc CCPR/C/OP/1 (1985), at page 124, paragraph 91). University of Minnesota, [1985]. 
lity. In its analysis of the merits of the Communication, the Human Rights Committee started 'from the premise that the State party is responsible for the action of the Finish Broadcasting Company (FBC), in which the State holds a dominant stake (90 percent) and which is placed under specific government control.58 While ultimately the Human Rights Committee held that there was no violation in this case, it is interesting to note that it started its analysis from the premise that by virtue of its State ownership of the FBC, Finland was responsible its actions.

15. Another important point to consider is the fact that UNGP 4 seems to focus on ownership broadly, which means that Principle 4 would be equally applicable in cases where the State is the full or majority owner of a SOE, as well as in those cases where the State is a minority shareholder. The focus in the second half of Principle 4 of the UNGPs on the indirect State ownership function reinforces this conclusion. That is, Principle 4 of the UNGPs would be applicable not only where the State owns or controls a given entity, but also in cases where completely independent business entities receive support and services from a SOE. The Commentaries to the UNGPs clarify this when they state that:

\begin{abstract}
Where these agencies do not explicitly consider the actual and potential adverse impacts on human rights of beneficiary enterprises, they put themselves at risk - in reputational, financial, political and potentially legal terms - for supporting such harm, and they may add to the human rights challenges faced by the recipient State. ${ }^{59}$
\end{abstract}

16. The second perspective on the State-business nexus is provided by Principle 5 of the UNGPs and provides that 'States must exercise adequate oversight in order to meet their international human rights obligations when they contract with, or legislate for, business enterprises to provide services that may impact on upon the enjoyment of human rights. ${ }^{300}$ Although not directly apparent

58 HERTZBERG, Leo et al. V. Finland: communication n. 61/1979, UN Doc CCPR/C/OP/1 (1985), at page 124, paragraph 91). University of Minnesota, [1985].

59 RUGGIE, John G. Guiding principles on business and buman rights: implementing the united nations "protect, respect and remedy" framework: report of the special representative of the secretarygeneral on the issue of human rights and transnational corporations and other business enterprises. (n. 2). p. 9.

60 RUGGIE, John G. Guiding principles on business and buman rights: implementing the united nations "protect, respect and remedy" framework: report of the special representative of the secretarygeneral on the issue of human rights and transnational corporations and other business enterprises. (n. 2). p. 9. from its text, the Commentary explains that Principle 5 applies to those situations where the State has privatised the delivery of certain services 'which may have an impact upon the enjoyment of human rights', meaning that States must adequately oversee the activities of those enterprises by providing 'adequate independent monitoring and accountability mechanisms. ${ }^{.61}$ Consequently, this shows that the State was once an owner, but has, in the meantime, privatised the provision of certain services, does not seem to dilute or diminish the obligations that States have to continually regulate and oversee those entities. The approach of Principle 5 of the UNGPs resonates with a considerable amount of academic research that has been undertaken concerning the adverse affects that privatisation could have on human rights, especially in sectors such as the provision of basic services, health, education, social security:

Taking into account this idea of the state as the ultimate entity vested with human rights obligations, it is obvious that the state has the duty to impose limits and conditions upon privatisations. This duty leads to the need to take a human rights approach to privatisation; human rights concerns must be present in every process of privatisation from the very beginning. There are two aspects in which the state can take part; first of all, the decision to privatise a given service that affects human rights obligations and second, the functioning of the service once it has been privatised. ${ }^{62}$

17. The third and last perspective on the State-business nexus is dealt with in Principle 6 of the UNGPs, which states that 'States should promote respect for human rights by business enterprises with which they conduct

RUGGIE, John G. Guiding principles on business and human rights: implementing the united nations "protect, respect and remedy" framework: report of the special representative of the secretary-general on the issue of human rights and transnational corporations and other business enterprises. (n. 2). p. 10.

RUGGIE, John G. Guiding principles on business and buman rights: implementing the united nations "protect, respect and remedy" framework: report of the special representative of the secretary-general on the issue of human rights and transnational corporations and other business enterprises. (n. 2).

61 RUGGIE, John G. Guiding principles on business and buman rights: implementing the united nations "protect, respect and remedy" framework: report of the special representative of the secretarygeneral on the issue of human rights and transnational corporations and other business enterprises. (n. 2).

62 FEYTER, Koen de; ISA, Felipe Gómes. Privatisation and buman rights in the age of globalisation. [S.1.]: Intersentia, 2005. (Maastricht Series in Human Rights). p. 18; LUSTIG, Doreen; BENVENISTI, Eyal. The multinational corporation as 'the good despot': the democratic costs of privatisation in global settings. 2013. Available at: <http:// globaltrust.tau.ac.il/publications $>$. 
commercial transactions. ${ }^{63}$ The scope of Principle 6 can be ascertained from the Commentary again, which draws attention to the fact that States conduct a 'variety of commercial transactions with business enterprises, not at least through their procurement activities.' The fact that the focus is on the totality of the commercial transactions in which a State may enter can be inferred from the use of the words 'not at least' present in the Commentary to the UNGPs. Thus, while the UNGPs acknowledge that procurement activities is one of the main forms in which States may engage with other businesses in commercial transactions, procurement is not by any means the only such method. For instance, States may enter into a multitude of commercial transactions as vendors of raw materials, or they may provide products (such as bonds or currencies) and services (such as labour) to businesses generally. ${ }^{64}$ Those transactions would also fall within the ambit of Principle 6. For example, one way through which States could practically implement the requirement of Principle 6 of the UNGPs is by ensuring that adequate consideration is given to human rights risks by integrating relevant contractual clauses in all contracts to which the State or SOEs are parties. ${ }^{65}$ That being said, procurement is still one of the main areas through which States can ultimately influence the conduct of other businesses, as far as the integration of human rights considerations in their activities is concerned, simply because State bureaucra-

63 RUGGIE, John G. Guiding principles on business and buman rights: implementing the united nations "protect, respect and remedy" framework: report of the special representative of the secretarygeneral on the issue of human rights and transnational corporations and other business enterprises. p. 10.

RUGGIE, John G. Guiding principles on business and human rights: implementing the united nations "protect, respect and remedy" framework: report of the special representative of the secretary-general on the issue of human rights and transnational corporations and other business enterprises. p. 9.

RUGGIE, John G. Guiding principles on business and human rights: implementing the united nations "protect, respect and remedy" framework: report of the special representative of the secretary-general on the issue of human rights and transnational corporations and other business enterprises. (n. 2).p. 9. (Emphasis added.)

64 INSTITUTE FOR HUMAN RIGHTS AND BUSINESS. State of play: human rights in the political economy of states: avenues for application. IHRB, 2014. Available at: <https://www.ihrb.org/ pdf/2014-03-18_State-of-Play_HR-Political-Economy-States.pdf $>$. 65 RUGGIE, John G. Principles for responsible contracts: integrating the management of human rights risks into state-investor contract negotiations: guidance for negotiators: report of the special representative of the secretary- general on the issue of human rights and transnational corporations and other business enterprises. 2011 (A/ HRC/17/31/Add.3) cies are some of the largest consumers of goods and services. For example, worldwide public procurement is worth EUR 1 trillion per year in trade flows, while in the EU alone, this figure amounts to EUR 425 billion, or approximately $3.4 \%$ of EU GDP. ${ }^{66}$ The EU Public Procurement Directives ${ }^{67}$ are some of the latest efforts to ensure that Member States implement a range of preventative, monitoring and capacity building actions, necessary to respond to the expectations' laid out in the UNGPs. ${ }^{68}$ The EU Public Procurement Directives seek to integrate human rights considerations across all phases of the procurement process, such as in pre-tender and in the market engagement phases, in the technical specifications phase, and in the selection, award and contracting phases. For example, all bidders that have failed to pay the required social security contributions, ${ }^{69}$ or that have been convicted of child labour or other forms of trafficking, ${ }^{70}$ or that do not comply with environmental, social and labour law obligations would be excluded from the tender process. ${ }^{71}$

18. This section has analysed the State-business nexus as covered by Principles 4, 5 and 6 of the UNGPs. It has shown that, by offering three perspectives on the State-business nexus, the UNGPs approach this concept very broadly. This approach is to a certain extent mirrored by the ILC Articles, which also seek to ensure that States are unable to avoid accountability by delegating functions that are normally associated with the State or through the outright control of private en-

66 INSTITUTE FOR HUMAN RIGHTS AND BUSINESS. Protecting rights by purchasing right: the human rights provisions, opportunities and limitations under the $2014 \mathrm{EU}$ public procurement directives. IHRB: London, 2015. (Occassional paper series paper number 3). p. 8.

67 DIRECTIVE 2014/23/EU of the European Parliament and of the Council of 26 February 2014 on the award of concession contracts [OJ L 94/1 (28 March 2014) (the "Concessions Directive")] 20142014; DIRECTIVE 2014/24/EU of the European Parliament and of the Council of 26 February 2014 on public procurement and repealing Directive 2004/18/EC [OJ L 94/65 (28 March 2014) (the "Public Sector Directive")]. 2014; DIRECTIVE 2014/25/EU of the European Parliament and of the Council of 26 February 2014 on procurement by entities operating in the water, energy, transport and postal services sectors and repealing Directive 2004/17/EC [OJ L 94/243 (28 March 2014) (the "Utilities Directive")].

68 Institute for Human Rights and Business (n. 67) 9.

69 Public Sector Directive Art. 57(2); Recital 105 and 106 of the Utilities Directive; Art. 38(5) of the Concessions Directive.

70 Public Sector Directive Art. 57(1)(f); Utilities Directive Art. 80; Art. 38(4)(f) of the Concessions Directive.

71 Public Sector Directive Art. 57(4)(a); Utilities Directive Art. 80; Art. 38(7)(a) of the Concessions Directive. 
tities. Under the UNGPs, the State has a duty to take 'additional steps' to ensure that the businesses that are directly and indirectly connected with the State protect against human rights abuses (UNGP Principle 4). Furthermore, just because a State was once the owner of a business does not mean that the obligations of the State to ensure that adequate oversight with regard to human rights, ended on the moment of privatisation (UNGP Principle 5). Consequently, States' obligations in this context are continuous. States should also ensure that other businesses with whom they conduct commercial transactions respect human rights, and for this purpose the net is cast wide to include the totality of the commercial transactions to which States or SOEs may become parties as vendors or purchasers (UNGP Principle 6).

\section{The content of the State duty to protect hUMAN RIGHTS IN THE CONTEXT OF the STATE- BUSINESS NEXUS}

19. Having considered the range of actors to whom the State-business nexus may be applicable, as well as the scope of this concept, which was approached from three perspectives, this section seeks to further analyse the content of the State duty to protect human rights in the context of the State-business nexus. For this purpose it will argue that the content of the State duty to protect human rights in the context of the State-business nexus is composed of two elements. The first element is the requirement to take 'additional steps' to protect against human rights abuses by businesses that are connected directly or indirectly with the State. The second element requires States to ensure that SOEs perform human rights due diligence on all their operations and activities, an element that could be considered as forming an integral part of the States' broader due diligence obligation to prevent human rights violations and which is generally required by international law..

\subsection{The first element: the requirement to take 'additional steps' by States as far as their SOEs are concerned}

20.It should be noted that when the State-business nexus is considered, apart from UNGPs 4, 5 and 6, it is clear that other Principles may come into play, such as the foundational principles outlined in UNGP 1, which deals with the general State duty to protect human rights; UNGP 2 which requires States to ensure that the 'expectation' that all business enterprises domiciled in their territory and/or jurisdiction respect human rights throughout their operations (a Principle which, through its policy-setting function, has the potential to influence corporate culture); UNGP 3, which sets out the State's general regulatory and policy function; and UNGP 8, which urges States to ensure that adequate 'policy coherence is achieved vertically as well as horizontally. For example, the Commentary to the UNGP clarifies the meaning of the expected policy coherence in the following way:

Vertical policy coherence entails States having the necessary policies, laws and processes to implement their international human rights law obligations. Horizontal policy coherence means supporting and equipping departments and agencies, at both the national and subnational levels, that shape business practices - including those responsible for corporate law and securities regulation, investment, export credit and insurance, trade and labour - to be informed of and act in a manner compatible with the Governments' human rights. ${ }^{72}$

21. But bearing in mind that in the context of the State-business nexus, States must take 'additional steps' to ensure that the entities that are directly or indirectly connected with the State do not perpetrate human rights abuses, what is the ultimate meaning of this term? What sort of 'additional steps' must States take in this regard that they would not usually have to take in the context of all corporations that are domiciled in their territory or jurisdiction? Does the inclusion of the requirement for 'additional steps', within the ambit of Principle 4 of the UNGPs, mean that more is expected from States? While there is nothing in scholarship that explicitly deals with this question, or anywhere in the UNGPs, the UN Working Group has dealt with this issue from two perspectives.

22. Firstly, during 2015 and 2016, the Working Group issued a report to the Human Rights Council that that focused on the State duty to protect human rights in the context of the State-business nexus titled 'Leading by example - The State, State-owned enterprises, and Hu-

72 RUGGIE, John G. Guiding principles on business and human rights: implementing the united nations "protect, respect and remedy" framework: report of the special representative of the secretarygeneral on the issue of human rights and transnational corporations and other business enterprises. (n. 2). p. 12. 
man Rights' ('Report'). ${ }^{73}$ This Report gives the following reasons why 'additional steps' must be taken by States in this area: 'policy coherence, legal obligations, reputation and credibility. ${ }^{74}$ While the issue of policy coherence and the State's legal obligations as a matter of international law in light of the ILC Articles have already been covered above, as far as reputation and credibility are concerned, the situation can be framed by asking the following question: if States are unwilling to ensure that the businesses that they own or control, or with whom they engage in commercial transactions respect human rights, then how could States expect any better from the private sector? In this context, this Report outlines the normative and policy framework that should underpin State action in relation to human rights, by examining the State duty to protect, ${ }^{75}$ the corporate responsibility to respect human rights, ${ }^{76}$ the link between corporate governance and human rights, ${ }^{77}$ urges SOEs to 'lead by example' and makes suggestions how the requirement to take 'additional steps' might be operationalized. ${ }^{78}$ The mechanics for operationalising the 'additional steps' focus on specific areas that target mainly issues of strategy and corporate governance. For example, the Report suggests that Sates: (i) set out clearly what ex-

73 UNITED NATIONS. Human Rights Concil. Promotion and protection of all buman rights, civil, political, economic, social and cultural rights, including the right to development: report of the working group on the issue of human rights and transnational corporations and other business enterprises. 2016. (A/HRC/32/45)

74 UNITED NATIONS. Human Rights Concil. Promotion and protection of all buman rights, civil, political, economic, social and cultural rights, including the right to development. report of the working group on the issue of human rights and transnational corporations and other business enterprises. 2016. (A/HRC/32/45). p. 1.

75 UNITED NATIONS. Human Rights Concil. Promotion and protection of all human rights, civil, political, economic, social and cultural rights, including the right to development. report of the working group on the issue of human rights and transnational corporations and other business enterprises. 2016. (A/HRC/32/45). p. 7.

76 UNITED NATIONS. Human Rights Concil. Promotion and protection of all human rights, civil, political, economic, social and cultural rights, including the right to development: report of the working group on the issue of human rights and transnational corporations and other business enterprises. 2016. (A/HRC/32/45). p. 9.

77 UNITED NATIONS. Human Rights Concil. Promotion and protection of all human rights, civil, political, economic, social and cultural rights, including the right to development: report of the working group on the issue of human rights and transnational corporations and other business enterprises. 2016. (A/HRC/32/45). p. 10.

78 UNITED NATIONS. Human Rights Concil. Promotion and protection of all buman rights, civil, political, economic, social and cultural rights, including the right to development. report of the working group on the issue of human rights and transnational corporations and other business enterprises. 2016. (A/HRC/32/45). p. 12-21. pectations they have from SOEs in the area of human rights and have mechanisms in place to manage those expectations; ${ }^{79}$ (ii) ensure that the relationship between the company boards and the State is clarified; ${ }^{80}$ (iii) ensure that there are oversight and follow up mechanisms in place for SOEs; ${ }^{81}$ (iv) aim for capacity building in this area; $^{82}$ (v) require human rights due diligence as well as disclosure, transparency and reporting mechanisms are put in place; ${ }^{83}$ (vi) ensure effective remedy. ${ }^{84} \mathrm{~A}$ handful of States have already started to make changes in this sense. For example, Sweden has recently changed its Official State Ownership Policy and has included business sustainability among some of its key targets. The Policy states that 'State-owned enterprises should act as role models within the area of sustainable business and should otherwise behave in a manner that promotes public confidence. ${ }^{95}$ The UNGPs as well as other corporate social responsibility initiatives such as the OECD Guidelines, Global Compact and the goals of the Agenda 2030 are specifically integrated in the Swe-

79 UNITED NATIONS. Human Rights Concil. Promotion and protection of all human rights, civil, political, economic, social and cultural rights, including the right to development: report of the working group on the issue of human rights and transnational corporations and other business enterprises. 2016. (A/HRC/32/45). p. 12.

80 UNITED NATIONS. Human Rights Concil. Promotion and protection of all buman rights, civil, political, economic, social and cultural rights, including the right to development: report of the working group on the issue of human rights and transnational corporations and other business enterprises. 2016. (A/HRC/32/45). p. 14-15.

81 UNITED NATIONS. Human Rights Concil. Promotion and protection of all human rights, civil, political, economic, social and cultural rights, including the right to development: report of the working group on the issue of human rights and transnational corporations and other business enterprises. 2016. (A/HRC/32/45). p. 16.

82 UNITED NATIONS. Human Rights Concil. Promotion and protection of all human rights, civil, political, economic, social and cultural rights, including the right to development: report of the working group on the issue of human rights and transnational corporations and other business enterprises. 2016. (A/HRC/32/45). p. 17.

83 UNITED NATIONS. Human Rights Concil. Promotion and protection of all buman rights, civil, political, economic, social and cultural rights, including the right to development: report of the working group on the issue of human rights and transnational corporations and other business enterprises. 2016. (A/HRC/32/45). p. 17-18.

84 UNITED NATIONS. Human Rights Concil. Promotion and protection of all buman rights, civil, political, economic, social and cultural rights, including the right to development: report of the working group on the issue of human rights and transnational corporations and other business enterprises. 2016. (A/HRC/32/45). p. 19.

85 GOVERNMENT OFFICES OF SWEDEN. Ministry of Enterprise and Innovation. The state's ownership policy and guidelines for state-owned enterprises 2017. Available at: <https://www.government. se/reports/2017/06/the-states-ownership-policy-and-guidelinesfor-state-owned-enterprises-2017/>. p. 4. 
dish State Ownership Policy ${ }^{86}$ Norway has made similar progress in this context and the aim of the Norwegian Government is for State ownership 'to be an example of best practice internationally,' and SOEs must act as 'exemplary' corporate citizens in four areas: climate and the environment, human rights, employee and worker rights and anticorruption. ${ }^{87}$ Norway's State Ownership Policy also integrates the UNGPs and there is a clear expectation from all SOEs to ensure that human rights are respected not only in their own operations but also by their business partners. ${ }^{88}$

23.Secondly, the UN Working Group has recently announced that it will currently focus on the 'operation of "economic diplomacy tools" such as export credit, investment guarantees, export promotion and trade missions, as well as public procurement', with the ultimate aim to develop concrete recommendations to be presented to the Human Rights Council in 2018. Those recommendations will be focusing on the requirement of the UNGPs for States to take 'additional steps' in order to ensure the protection and promotion of human rights in the 'State-business nexus'. ${ }^{89}$ The latest recommendations were published at the time of writing this article, but overall the two initiatives seems to suggest that, at least at UN level, a new paradigm is now forming, whereby more is expected from SOEs than from privately-owned corporations as far as the responsibility to respect human rights is concerned. In this context, some scholars have remarked that SOEs 'occupy a dual

86 UNITED NATIONS. Human Rights Concil. Promotion and protection of all human rights, civil, political, economic, social and cultural rights, including the right to development: report of the working group on the issue of human rights and transnational corporations and other business enterprises. 2016. (A/HRC/32/45).

87 NORWEGIAN MINISTRY OF TRADE, INDUSTRY AND FISCHERIES. Diverse and value-creating ownership: Meld. St. 27 (2013-2014): report to the storting (white paper): recommendation of the Ministry of Trade, Industry and Fisheries of 20 june 2014, approved in the Council of State the same day. 2014. (The Solberg Government) < https://www.regjeringen.no/en/dokumenter/ meld.-st.-27-2013-2014/id763968/>.

88 NORWEGIAN MINISTRY OF TRADE, INDUSTRY AND FISCHERIES. Diverse and value-creating ownership: Meld. St. 27 (2013-2014): report to the storting (white paper): recommendation of the Ministry of Trade, Industry and Fisheries of 20 june 2014, approved in the Council of State the same day. 2014. (The Solberg Government) < https://www.regjeringen.no/en/dokumenter/ meld.-st.-27-2013-2014/id763968/>. p. 84.

89 UN WORKING GROUP ON BUSINESS AND HUMAN RIGHTS. The state as an economic actor and human rights: further unpacking practical implications of international business and human rights principles for the "state-business nexus".[S.l.:s.n., 20--?] place within the UNGPs', in that they may be considered as instrumentalities of the State and thus 'potentially subject to the State duty to protect' while at the same time they are 'commercial ventures being subject to the corporate responsibility to respect..$^{90}$ This means that in the case of SOEs, all Pillars of the UNGPs may be applicable concomitantly since as Principle 14 of the UNGPs states 'the responsibility of business enterprises to respect human rights applies to all enterprises regardless of their size, sector, operational context, ownership and structure.' However, a further differentiation seems to be made by the UN Working between SOEs and privately owned entities when it states that 'in addition to' to the responsibility of SOEs to respect human rights, they are expected to observe 'the highest standards of business conduct on par with listed companies. ${ }^{91}$ However, despite the focus in this article on SOEs, the UN Working Group has clarified that, just because States may have to take 'additional steps' to ensure that SOEs respect human rights, this does not mean that States should be less concerned with the activities of privately-owned entities:

This does not mean that States should pay less
attention to ensuring respect for human rights by
fully private enterprises. The ultimate goal is the
full respect for human rights by all enterprises,
irrespective of size, sector, operational context,
structure or ownership. As States work towards
that goal, there are still persuasive reasons for them
to lead by example. This will only strengthen their
legitimacy in setting regulations and expectations
towards private businesses.

4.2. The second element: due diligence 'requirements' by SOEs as a integral element of States' due diligence obligations

24. This section deals with the second element of the content of States' obligations to protect human rights in the context of the State-business nexus. That is, in accordance with Principle 4, States may 'require' their SOEs to perform human rights due diligence on their operations, 'where' this is considered as an 'appropriate' step. Consequently, it is clear that as it currently

90 BACKER, Larry Catá. The human rights obligations of State Owned Enterprises (SOEs). (n. 18). p. 1-2.

91 'Leading by Example: The State, State-Owned Enterprises and Human Rights (Report of the Working Group on the Issue of Human Rights and Transnational Corporations and Other Business Enterprises). (n. 28). p. 10.

92 Human Rights Council (n. 74). p. 21. 
stands, this 'requirement' is not mandatory because of the presence of the words 'where appropriate.' However, even if those words would not have been included in UNGP Principle 4, it is unlikely that States would have been 'required' to perform mandatory due diligence on all the operations of their SOEs. As explained in the introduction to this article, the UNGPs are a 'soft law' instrument that do not create any hard obligations, but may ultimately influence States as well as corporations to change their behaviour. ${ }^{93}$ Nevertheless, the requirements that States must take 'additional steps' under Principle 4 of the UNGPs have to be viewed in light of the broader obligations to 'protect, respect and fulfill' that States already have under the international human rights law. ${ }^{95}$ Those obligations are both of a negative and positive nature. ${ }^{96}$ For example, under the duty to respect human rights, States have a negative obligation to refrain from interfering with the enjoyment of any human rights. ${ }^{97}$ By way of example, States would violate the negative duty to respect human rights, if they would prioritise business interests over human rights, without an adequate justification for doing so. ${ }^{98}$ The duty to protect and the duty to fulfill human rights are of a positive nature, which means that this duty imposes requirements for a standard of conduct rather than a standard of result. ${ }^{99}$ In ensuring an adequate standard of conduct, States

93 SHAW, Malcolm N. International law. 7. ed. Cambridge: Cambridge Univ Press, 2014. (n. 6). p. 182-183.

94 SHUE, Henry. The interdependence of rights: the right to food. Leida: Martinus Nijhoff Publishers, 1984. p. 83-84.

95 SCHUTTER, Olivier de. International human rights law: cases, materials, commentary. 2. ed. Cambridge: Cambridge University Press, 2014. p. 280-291.

96 UNITED NATIONS. Office of the United Nations High Commissioner for Human Rights. Principles and guidelines for a buman rights approach to poverty reduction strategies. 2012. (HR/PUB/06/12). p. 48.

97 UNITED NATIONS. General Comment n. 31 (2004) on Art 2 of the ICCPR: the Nature of the general legal obligation imposed on states parties to the covenant, 2004 para 6. ('The legal obligation under article 2, paragraph 1 is both negative and positive in nature. State Parties must refrain from violation of the rights recognised by the Covenant, and any restriction on those rights must be permissible under the relevant provision of the Covenant.')

98 UNITED NATIONS. Economic on Economic, Social and Cultural Rights. General comment n. 24 (2017) on State obligations under the International Covenant on Economic, Social and Cultural Rights in the context of business activities, 2017. p. 12; AUGENSTEIN, Daniel. State responsibilities to regulate and adjudicate corporate activities under the European Convention on Human Rights: Submission to the Special Representative of the United Nations Secretary-General (SRSG) on the issue of Human Rights and Transnational Corporations and Other Business Enterprises, 2011.

99 UNITED NATIONS. Human Rights Council: promotion of all must take appropriate steps to prevent, investigate, punish and provide appropriate redress when human rights violations have in fact occurred. ${ }^{100}$ While States' discretion in how exactly to go about this issue is preserved, in practice such Steps are implemented by taking legislative, administrative, judicial, financial, educational and social measures, ${ }^{101}$ a fact that is also reinforced in the text of Principle 3 of the UNGPs. ${ }^{102}$ Furthermore, as evidenced by jurisprudence, overall the positive obligation to protect against human rights abuses is composed of several different elements, such as substantive obligations, which are normally implemented through legislation, ${ }^{103}$ procedural obligations to investigate and punish human rights abuses ${ }^{104}$ and an obligation to monitor high-risk activities. ${ }^{105}$ Consequently, in the context of States' positive duty to protect human rights and the State-business nexus, the obligation to monitor high-risk activities is likely to imply an obligation to conduct due diligence

human rights, civil, political, economic, social and cultural rights, including the right to development: business and human rights: towards operationalizing the "protect, respect and remedy" framework: report of the special representative of the Secretary-General on the issue of human rights and transnational corporations and other business enterprises. 2009. (A/HRC/11/13). p. 13.

100 UNITED NATIONS. Human Rights Council: promotion of all human rights, civil, political, economic, social and cultural rights, including the right to development: business and human rights: towards operationalizing the "protect, respect and remedy" framework: report of the special representative of the Secretary-General on the issue of human rights and transnational corporations and other business enterprises. 2009. (A/HRC/11/13). p. 14.

101 General Comment 3, The nature of States parties obligations (Art. 2, par.1 of the ICESCR): 14/12/90. 1990 para 7. UNITED NATIONS. Office of the High Commissioner for Human Rights. CESCR General Comment 3, The nature of States parties obligations: art. 2, par. 1 of the ICESCR. 14 dez. 1990.

102 UNGP Principle 3 states that: 'In meeting their duty to protect, States should: (a) Enforce laws that are aimed at, or have the effect of, requiring business enterprises to respect human rights, and periodically to assess the adequacy of such laws and address any gaps; (b) Ensure that other laws and policies governing the creation and ongoing operation of business enterprises, such as corporate law, do not constrain but enable business respect for human rights; (c) Provide effective guidance to business enterprises on how to respect human rights throughout their operations; (d) Encourage, and where appropriate require, business enterprises to communicate how they address their human rights impacts.'

103 CASE of López Ostra v Spain. ECHR, 1990. (Application n. 16798/90). p. 51-53; CASE of Tatar v Romaina. ECHR, 2001. (Application n. 67021/01). p. 88.

104 CASE of Hatton \& ors v United Kingdom. ECHR, 1997. (Application n. 36022/97). p. 104.

105 LAGOUTTE, Stephanie. The state duty to protect against businessrelated human rights abuses: unpacking Pillar 1 and 3 of the UN Guiding Principles on Human Rights and Business. Copenhagen: Danish Institute for Human Rights, 2014. (Ano 2014/1). p. 13. 
on those activities. For example, if States own or control SOEs, or conduct commercial transactions with entities that operate in certain high-risk activities, States would have an obligation, as a matter of international law, to monitor the activities of those entities by performing continuous due diligence, as discussed above in the context of Principles 4, 5 and 6 of the UNGPs.

25. Since the UNGPs have been endorsed in 2011, there has been an increased focus on the concept of due diligence in the context of the corporate responsibility to respect human rights under Pillar II of the UNGPs. However, it should be recalled that due diligence is a principle that is well entrenched in international law, and which forms a core part of the State's duty to protect human rights, as has been established in cases such as Velàsquez-Rodriguezv Honduras where the Inter-American Court of Human Rights stated that:

An illegal act which violates human rights and which
is initially not directly imputable to a State (for
example, because it is the act of a private person
or because the person responsible has not been
identified) can lead to international responsibility of
the State, not because of the act itself, but because
of the lack of due diligence to prevent the violation
or to respond to it as required by the Convention. ${ }^{106}$

26. In this context, as it was clarified by the International Court of Justice, due diligence implies the obligation to 'employ all means reasonably available' to avoid a negative outcome. ${ }^{107}$ However, States' due diligence obligations should not be confused with the concept of 'human rights due diligence', which is a relatively newer concept introduced by the UNGPs, and which can be expressly found in UNGPs 17 to $21 .{ }^{108}$ This is because, as mentioned above, States' due diligence obligations

106 VELÀSQUEZ Rodríguez, v Honduras: Judgment of july 29, 1988, Inter-AmCtHR (Ser C) n. 4 (1988). University of Minnesota, [1988]. p. 172.

107 APPLICATION of the Convention on the Prevention and Punishment of the Crime of Genocide: Bosnia and Herzegovina v Serbia and Montenegro. Judgment, ICJ Reports 2007. p. 43 [430]. ([I] $\mathrm{t}$ is clear that the obligation in question is one of conduct and not one of result, in the sense that a State cannot be under an obligation to succeed, whatever the circumstances, in preventing the commission of genocide; the obligation of States parties is rather to employ all means reasonably available to them, so as to prevent genocide as far as possible.)

108 For example, UNGP Principle 17 states that 'in order to identify, prevent, mitigate and account for how they address their adverse human rights impacts, business enterprises, should carry out human rights due diligence.' Human rights due diligence is thus viewed as a 'process' which involves 'assessing actual and potential human rights impacts, integrating and acting upon the findings, tracking responses and communicating how impacts are addressed.' arise as a matter of international law, ${ }^{109}$ while 'human rights due diligence' is a voluntary mechanism that targets business enterprises generally and which ensures that businesses 'can identify, prevent, mitigate and account for the harms that they may cause, and through which judicial and regulatory bodies, can assess and enterprise's respect for human rights. ${ }^{110}$ Furthermore, a recent empirical study, which analysed State practice that spanned more than 100 jurisdictions, has concluded that due diligence is 'not a creation of the UN Human Rights Council nor [is it] a voluntary measure for corporate social responsibility', because it 'originates from the legal tools that States are already using to ensure that business behaviour meets social expectations, including standards set in law. ${ }^{111}$

27. Another issue to consider - which further supports the argument that States are have an obligation as a matter of international law to perform due diligence in the context of the State-business nexus - is that it is only reasonable to assume that a State should be aware about how its SOEs operate, given the fact that it is the State that ultimately sets out the operational strategy for all its SOEs, as the official State Ownership Policies of Sweden and Finland have already showed. There are further examples, in this regard, which support the argument that States are very well aware of the manner in which their SOEs operate. For example, in China the State-owned Assets Supervision and Ad-

109 BONNITCHA, Jonathan; MCCORQUODALE, Robert. The concept of "due diligence" in the un guiding principles on business and human rights. European Journal of International Law, v. 28, Issue 3, p. 899-919, nov. 2017. p. 904-905.

110 SCHUTTER, Olivier de et al. Human rights due diligence: the role of states. 2012. Available at: <http://humanrightsinbusiness. eu/wp-content/uploads/2015/05/De-Schutter-et-al.-HumanRights-Due-Diligence-The-Role-of-States.pdf $>$.; Bonnitcha and McCorquodale (n. 110). p. 907. For example, Bonnitcha and McCorquodale argue that there could be some negative consequences of the fact that due diligence is viewed as a process rather than a legal requirement by businesses. Firstly, it is believed that this 'encourages the incorrect view that implementing due diligence processes is sufficient to discharge businesses' responsibility to respect human rights' (at 910). Secondly, the authors believe that 'the failure to distinguish between the two different meanings of due diligence creates confusion about he situations in which businesses that infringe human rights can be said to have breached their responsibility to respect human rights and, therefore, to have a responsibility to provide a remedy within the scheme established by the Guiding Principles.')

111 SCHUT'TER, Olivier de et al. Human rights due diligence: the role of states. 2012. Available at: <http://humanrightsinbusiness. eu/wp-content/uploads/2015/05/De-Schutter-et-al.-HumanRights-Due-Diligence-The-Role-of-States.pdf $>$. p. 4. 
ministration Commission (SASAC) is the agency that sets the strategy for all of China's SOEs. ${ }^{112}$ SASAC has recently issued certain Guidelines to the State-owned Enterprises Directly under the Central Government on Fulfilling Corporate Social Responsibilities. ${ }^{113}$ Those Guidelines require that SOEs operate their business in a legal and honest manner, make sustainable profits, improve their products and services, fulfill their corporate social responsibilities, engage with communities, conserve resources, and protect the environment and the legal rights of their employees in their operations. The main measures that SOEs should take is to increase awareness of corporate social responsibility, set up procedures in this regard, including associated reporting, and increase dialogue and international cooperation. The Guidelines are clear that in doing so it will help China in 'establishing a "responsible" public image'. ${ }^{114}$ The Ministry of Commerce and the Ministry of Environmental Protection have also issued a Guidance on Environmental Protection in Foreign Investment and Cooperation, which states that all enterprises operating abroad should: have measures in place to ensure environmental protection; respect the religions and customs of the host State; respect the environmental laws of the host State; and should conduct environmental impact assessments. ${ }^{115}$

28. SOEs are also 'encouraged to study and learn from environmental principles, standards and practices of international organisations and multinational financial institutions. ${ }^{, 16}$ The China Banking and Regulatory

112 SASAC About SASAC - SASAC Main Functions - SASAC. Available at: <http://en.sasac.gov.cn/n1408028/n1408521/index. html>.

113 STATE-OWNED ASSETS SUPERVISION AND ADMINISTRATION COUNCIL. Guidelines to the State-owned enterprises directly under the central government on fulfilling corporate social responsibilities. Available at: <http://en.sasac.gov.cn/n1408035/c1477196/content.html>.

114 STATE-OWNED ASSETS SUPERVISION AND ADMINISTRATION COUNCIL. Guidelines to the State-owned enterprises directly under the central government on fulfilling corporate social responsibilities. Available at: <http://en.sasac.gov.cn/n1408035/c1477196/content.html>.

115 MINISTRY OF COMMERCE PEOPLES'S REPUBLIC OF CHINA. MOFCOM and MEP jointly issued guidance on environmental protection in foreign investment and cooperation. 2013. Available at: $<$ http://english.mofcom.gov.cn/article/newsrelease/significantnews/201303/20130300043146.shtml>.

116 MINISTRY OF COMMERCE PEOPLES'S REPUBLIC OF CHINA. MOFCOM and MEP jointly issued guidance on environmental protection in foreign investment and cooperation. 2013. Available at: $<$ http://english.mofcom.gov.cn/article/newsrelease/significant-
Commission has also issued the Green Credit Guidelines whose purpose is to require banks that finance overseas investment to strengthen environmental and corporate social responsibility requirements. ${ }^{117}$ Article 21 of the Green Credit Guidelines requires banks to ensure that the businesses they lend to respect the host State laws and regulations concerning the environment and 'make a promise in public that appropriate international practices or international norms will be followed'. Some other sector specific instruments, such as the Guidelines for Social Responsibility in Outbound Mining Investments do expressly incorporate the UNGPs and state that those companies must 'observe the UN Guiding Principles on Business and Human Rights during the entire lifecycle of the mining project. ${ }^{118}$ In late 2017, the China Chamber of Commerce of Metals, Minerals and Chemical Importers and Exporters entered into a formal agreement with the International Council on Mining and Metals to 'help promote sustainable development in Chinese companies' overseas mining investments. ${ }^{119}$

29. Overall, this section has shown that the concept of due diligence sits at the heart of the second element of the State-business nexus. While the UNGPs do not impose additional obligations on States and the language used therein does not indicate that States would have to always perform due diligence in the context of the State-business nexus, it was argued that States may be required to so anyway, in order to comply with their obligations under international law to 'protect, respect and fulfill' human rights. This is because States, as part of the positive duty to respect human rights, must monitor high-risk activities. Furthermore, it is only reasonable to assume that States should know how the entities that they own or control operate, given that they ultimately set the operational strategy for all those entities.

news/201303/20130300043146.shtml>.

117 NOTICE of the CBRC on issuing the green credit guidelines. Available at: <http://www.cbrc.gov.cn/EngdocView.do?docI $\mathrm{D}=3$ CE646AB629B46B9B533B1D8D9FF8C4A>.

118 CHINA. China Chamber of Commerce of Metals, Minerals \& Chemicals Importers \& Exporters. CCMCMC Guidelines for Social Responsibility in Outbound Mining Investments. 2014

119 INTERNATIONAL COUNCIL ON MINING E METALS (ICMM). Chinese mining body aligns with icmm to promote mining with principles. 2017. Available at: <https://www.icmm.com/en-gb/ news /2017/icmm-signs-mou-with-cccmc $>$. 


\section{Conclusion}

30. This article has sought to understand how the UNGPs address the State-business nexus. It has been shown that this concept entered into the narrative of the UNGPs relatively early on and that Professor Ruggie understood that States must also be engaged in addressing human rights challenges in their own right as economic actors, and not just in their capacity as States. This ultimately led to the inclusion in the UNGPs of Principles 4, 5 and 6. In this context, it has been shown that, although the UNGPs were not initially clear who exactly were the actors that fell within the ambit of the State-business nexus, later developments suggested that the approach adopted is very broad and that it includes all manner of entities that are owned or controlled by States, regardless of how they are formally structured from a legal point of view. Furthermore, a close examination of the State-business nexus leads to the conclusion that there are three perspectives from which this concept is approached in the UNGPs. Principle 4 applies to those entities that are owned or controlled by the State or that receive substantial support and services from the State. Principle 5 applies equally to privately owned entities that may operate in certain sectors that were previously State-owned. Principle 6 applies to all other entities with whom States may enter into commercial transactions. It has been argued that the coverage by the UNGPs of the State-business nexus from three perspective mirrors to a certain extent - the broad approach adopted by the ILC Articles 4, 5 and 8, which also seek to ensure that States are ultimately accountable for the acts of those entities, when it is not initially apparent how those entities fit in the structure of the State. An investigation into the content of the State-business nexus concluded that this concept is composed of two elements. The first element requires States to take 'additional steps' to ensure that the entities that are owned, controlled or 'that receive substantial support and services' from the State behave as model corporate citizens. The second element of the State-business nexus deals with the 'requirement' to perform due diligence in certain circumstances. In this context, it has been argued that, while a strict interpretation of this element in the context of the UNGPs does not indicate that this is a mandatory requirement, its interpretation in light of the broader State obligations to 'protect, respect and fulfill' human rights seems to indicate that this is nevertheless the case. This would ultimately mean that States have an obligation to perform due diligence on all the activities of their SOEs as part of their obligation to monitor high-risk activities. This conclusion is also supported by a reasonable expectation that States should know how the entities that they own or control operate, given that in the great majority of cases, it is the State that ultimately sets out the operational strategy of those entities.

\section{References}

APPLICATION of the Convention on the Prevention and Punishment of the Crime of Genocide: Bosnia and Herzegovina v Serbia and Montenegro. Judgment, ICJ Reports 2007.

APPLICATION of the International Convention on the Elimination of All Forms of Racial Discrimination: Georgia v Russian Federation. Provisional Measures (No 2008/35). 15 oct. 2008.

AUGENSTEIN, Daniel. State responsibilities to regulate and adjudicate corporate activities under the European Convention on Human Rights: Submission to the Special Representative of the United Nations Secretary-General (SRSG) on the issue of Human Rights and Transnational Corporations and Other Business Enterprises, 2011.

BACKER, Larry Catá. Between state, company, and market: a preliminary engagement on the business and human rights obligations of States and State Owned Enterprises (SOEs). Available at: <https://ssrn.com/ abstract $=2869944>$.

BACKER, Larry Catá. Corporate social responsibility in weak governance zones. Santa Clara J. Int'l L., v. 14, n. 297, p. 297-323, 2016. Available at: < http://digitalcommons.law.scu.edu/scujil/vol14/iss1/10>.

BACKER, Larry Catá. Sovereign investing in times of crisis: global regulation of sovereign wealth funds, state owned enterprises and the chinese experience. Transnational Law \& Contemporary Problems, v. 19, n. 1, 2009.

BACKER, Larry Catá. The human rights obligations of State Owned Enterprises (SOEs): emerging conceptual structures and principles in national and international law and policy. Vanderbilt Journal of Transnational Law, v. 51, 2017. Available at: <https://papers.ssrn.com/sol3/ papers.cfm?abstract_id $=2980533>$. 
BASSAN, Fabio. The law of sovereign wealth funds. Edward Elgar, 2011.

BERNAZ, Nádia. Business and buman rights: history, law and policy: bridging the accountability gap. Londres: Routlege, 2017.

BOLTON, Patrick; SAMAMA, Frederic; STIGLITZ, Joseph E. (Ed.). Sovereign wealth funds and long-term investing. New York: Columbia University Press, 2012.

BONNITCHA, Jonathan; MCCORQUODALE, Robert. The concept of "due diligence" in the un guiding principles on business and human rights. European Journal of International Law, v. 28, Issue 3, p. 899-919, nov. 2017.

BUHMANN, Karin. Navigating from "train wreck" to being "welcomed": negotiation strategies and argumentative patterns in the development of the UN framework. In. DEVA, Surya; BILCHITZ, David (Ed.). Human rights obligations of business: beyond the corporate responsibility to respect. Cambridge: Cambridge University Press, 2013.

CAN, Özgür; SECK, Sara L. The legal obligations with respect to human rights and export credit agencies: final legal discussion paper: july 2006. Ottawa: Halifax Intiative Coalition, 2006. p. 23. Available at: <http://www.halifaxinitiative.org/content/legal-obligations-respect-human-rights-and-export-credit-agencies-june-23-2006>. Accessed: 20 jun. 2018.

CASE Concerning Barcelona Traction, Light and Power Company, Limited: Belgium v Spain. Judgment, ICJ Reports 1970.

CASE of Dubetska \& ors v Ukraine. ECHR, 2003. (Application n. 30499/03)

CASE of Fadeyeva v Russia. ECHR, 2005. (Application n. 55723/00, 9 June 2005)

CASE of Hatton \& ors v United Kingdom. ECHR, 1997. (Application n. 36022/97)

CASE of Heinisch v Germany. ECtHR, 2008. (Application n. 28274/08, Judgment 21 July 2011)

CASE of López Ostra v Spain. ECHR, 1990. (Application n. 16798/90)

CASE of Tatar v Romaina. ECHR, 2001. (Application n. $67021 / 01)$

CASE of Yershova v Russia. ECHR, 2004. (Application n. 1387/04, 8 April 2010)

CHINA. China Chamber of Commerce of Metals, Minerals \& Chemicals Importers \& Exporters. CCMCMC Guidelines for Social Responsibility in Outbound Mining Investments. 2014.

CLAPHAM, Andrew. Human rights obligations of non-state actors. Oxford: OUP Oxford, 2006.

CRAWFORD, James. State responsibility: the general part. Cambridge: Cambridge Univ. Press, 2014. (1. Paperback ed.).

DEVA, Surya. Regulating corporate human rights violations: humanizing business. Londres: Routledge, 2014.

DEVA, Surya. Treating human rights lightly: a critique of the consensus rhetoric and the language employed by the guiding principles: human rights obligations of business: beyond the corporate responsibility to respect. Cambridge: Cambridge University Press, 2013.

DIRECTIVE 2014/23/EU of the European Parliament and of the Council of 26 February 2014 on the award of concession contracts [OJ L 94/1 (28 March 2014) (the "Concessions Directive")].

DIRECTIVE 2014/24/EU of the European Parliament and of the Council of 26 February 2014 on public procurement and repealing Directive 2004/18/EC [OJ L 94/65 (28 March 2014) (the "Public Sector Directive")].

DIRECTIVE 2014/25/EU of the European Parliament and of the Council of 26 February 2014 on procurement by entities operating in the water, energy, transport and postal services sectors and repealing Directive 2004/17/EC [OJ L 94/243 (28 March 2014) (the "Utilities Directive").]

DRAFT articles on responsibility of states for internationally wrongful acts. 2001.

FEYTER, Koen de; ISA, Felipe Gómes. Privatisation and buman rights in the age of globalisation. Intersentia, 2005. (Maastricht Series in Human Rights)

GIANTURCO, Delio E. Export credit agencies: the unsung giants of international trade and finance. Santa Barbára: Greenwood Publishing Group, 2001.

GOVERNMENT OFFICES OF SWEDEN. Ministry of Enterprise and Innovation. The state's ownership policy and guidelines for state-owned enterprises. 2017. Available at: < https://www.government.se/reports/2017/06/the- 
states-ownership-policy-and-guidelines-for-state-owned-enterprises-2017/>.

HERTZBERG, Leo et al. V. Finland: communication n. 61/1979, UN Doc CCPR/C/OP/1 (1985), at page 124, paragraph 91). University of Minnesota, 1985.

HULTS, David R.; VICTOR, David G.; THURBER, Mark (Ed.). Oil and governance: state-owned enterprises and the world energy supply. Cambridge: Cambridge University Press, 2012.

INSTITUTE FOR HUMAN RIGHTS AND BUSINESS (IHRB). Letter to the Members of the G20 Employment Working Group. 24 mar. 2017.

INSTITUTE FOR HUMAN RIGHTS AND BUSINESS. Protecting rights by purchasing right: the human rights provisions, opportunities and limitations under the 2014 EU public procurement directives. IHRB: London, 2015. (Occassional paper series paper number 3).

INSTITUTE FOR HUMAN RIGHTS AND BUSINESS. State of play: human rights in the political economy of states: avenues for application. IHRB, 2014. Available at: <https://www.ihrb.org/pdf/2014-03-18_ State-of-Play_HR-Political-Economy-States.pdf $>$.

INTERNATIONAL COUNCIL ON MINING E METALS (ICMM). Chinese mining body aligns with icmm to promote mining with principles. 2017. Available at: <https:// www.icmm.com/en-gb/news/2017/icmm-signs-mouwith-cccmc $>$.

INTERNATIONAL COURT OF JUSTICE. Military and paramilitary activities in and against Nicaragua: Nicaragua v United States of America. Merits, Judgment ICJ Reports 1986.

INTERNATIONAL LABOUR ORGANIZATION. Tripartite declaration of principles concerning multinational enterprises and social policy: adopted by the Governing Body of the International Labour Office at its 204th Session (Geneva, November 1977) $f$ nd amended at iis 279th (November 2000), 295th (March 2006) and 329th (March 2017) Sessions). Geneva: ILO, 2017.

LAGOUTTE, Stephanie. The state duty to protect against business-related buman rights abuses: unpacking Pillar 1 and 3 of the UN Guiding Principles on Human Rights and Business. Copenhagen: Danish Institute for Human Rights, 2014. (Ano 2014/1)

LEE, Jaemin. State responsibility and government-affiliated entities in international economic law: the danger of blurring the chinese wall between 'state organ'and 'non-state organ'as designed in the ilc draft articles. Journal of World Trade, v. 49, Issue 1, 2015.

LUSTIG, Doreen; BENVENISTI, Eyal. The multinational corporation as 'the good despot': the democratic costs of privatisation in global settings. 2013. Available at: $<$ http://globaltrust.tau.ac.il/publications $>$.

MCCORQUODALE, Robert. The impact of international human rights law on state responsibility. In: KAMMINGA, Menno; SCHEININ, M. (Ed.). The impact of human rights on general international law. Oxford: Oxford University Press, 2009.

MINISTRY OF COMMERCE PEOPLES'S REPUBLIC OF CHINA. MOFCOM and MEP jointly issued guidance on environmental protection in foreign investment and cooperation. 2013. Available at: <http://english. mofcom.gov.cn/article/newsrelease/significantnews/201303/20130300043146.shtml>.

NATIONAL oil companies: beyond boundaries, beyond borders: an emerging class of multinational oil companies is changing the competitive landscape. Available at: <http://www.bain.com/publications/articles/national-oil-companies-beyond-boundaries.aspx> .

NORWEGIAN MINISTRY OF TRADE, INDUSTRY AND FISCHERIES. Diverse and value-creating ownership: Meld. St. 27 (2013-2014): report to the storting (white paper): recommendation of the Ministry of Trade, Industry and Fisheries of 20 june 2014, approved in the Council of State the same day. 2014. (The Solberg Government). Available at: < https://www.regjeringen.no/en/dokumenter/meld.-st.-27-2013-2014/ $\operatorname{id} 763968 />$.

NOTICE of the CBRC on issuing the green credit guidelines. Available at: <http://www.cbrc.gov.cn/ EngdocView.do?docID=3CE646AB629B46B9B533B1 D8D9FF8C4A>.

NOTICE of the CBRC on issuing the green credit guidelines. Available at: <http://www.cbrc.gov.cn/ EngdocView.do?docID=3CE646AB629B46B9B533B1 D8D9FF8C4A>.

OECD guidelines for multinational enterprises: 2011 edition. Paris: OECD Publishing, 2011.

RAJAVUORI, Mikko. State ownership and the united nations business and human rights agenda: three instruments, three narratives. Indiana Journal of Global Legal 
Studies, v. 23, n. 2, summer, 2016.

RUGGIE, John G. Business and buman rights: further steps toward the operationalization of the "protect, respect and remedy" framework: report of the special representative of the secretary- general on the issue of human rights and transnational corporations and other business enterprises. 2010. (A/HRC/14/27)

RUGGIE, John G. Human rights and corporate law: trends and observations from a crossnational study conducted by the special representative: report of the special representative of the secretary-general on the issue of human rights and transnational corporations and other business enterprises. 2011. (A/HRC/17/31/Add.2)

RUGGIE, John G. Summary of five multi-stakeholder consultations: report of the special representative of the secretary-general on the issue of human rights and transnational corporations and other business enterprises. 2008. (A/HRC/8/5/Add.1)

RUGGIE, John G. Corporations and human rights: a survey of the scope and patterns of alleged corporate-related human rights abuse: report of the special representative of the secretary-general on the issue of human rights and transnational corporations and other business enterprises. 2008. (A/HRC/8/5/Add.2)

RUGGIE, John G. Guiding principles on business and human rights: implementing the united nations "protect, respect and remedy" framework: report of the special representative of the secretary-general on the issue of human rights and transnational corporations and other business enterprises. 2011. (A/HRC/17/31)

RUGGIE, John G. Principles for responsible contracts: integrating the management of human rights risks into state-investor contract negotiations: guidance for negotiators: report of the special representative of the secretary- general on the issue of human rights and transnational corporations and other business enterprises. 2011. (A/HRC/17/31/Add.3)

RUGGIE, John G. Promotion and protection of human rights: interim report of the special representative of the secretary-general on the issue of human rights and transnational corporations and other business enterprises. 2006. (E/CN.4/2006/97)

RUGGIE, John G. Protect, respect and remedy: a framework for business and human rights: report of the special representative of the secretary-general on the issue of human rights and transnational corporations and other business enterprises, John Ruggie. 2008. (A/HRC/8/5)

RUGGIE, John G. State obligations to provide access to remedy for buman rights abuses by third parties, including business: an overview of international and regional provisions, commentary and decisions (report of the special representative of the secretary-general on the issue of human rights and transnational corporations and other business enterprises. 2009. (A/HRC/11/13/Add.1)

RUGGIE, John G. State responsibilities to regulate and adjudicate corporate activities under the united nations core buman rights treaties: an overview of treaty body commentaries: report of the special representative of the secretarygeneral on the issue of human rights and transnational corporations and other business enterprises. Kennedy School of Government; Harvard Law Schooll, 2007. (A/HRC/4/35/Add.1)

SASAC About SASAC: SASAC main functions. Available at: <http://en.sasac.gov.cn/n1408028/n1408521/ index.html>.

SAUVANT, Karl P. The negotiations of the united nations code of conduct on transnational corporations: experience and lessons learned. The Journal of World Investment and Trade, v. 16, p. 11-87, 2015.

SCHUTTER, Olivier de et al. Human rights due diligence: the role of states. 2012. Available at: <http://humanrightsinbusiness.eu/wp-content/uploads/2015/05/ De-Schutter-et-al.-Human-Rights-Due-Diligence-TheRole-of-States.pdf $>$.

SCHUTTER, Olivier de. International human rights law: cases, materials, commentary. 2. ed. Cambridge: Cambridge University Press, 2014.

SERGIE, Mohamemed Aly. Qatar petroleum expanding overseas with focus on production. Bloomberg.com. 23 jun. 2015. Available at: <http://www.bloomberg. com/news/articles/2015-06-23/qatar-petroleum-eyesforeign-expansion-after-restructuring $>$.

SHAW, Malcolm N. International law. 7. ed. Cambridge: Cambridge Univ Press, 2014. p. 182-183.

SHELTON, Dinah L. 'Soft law', handbook of international law. Routledge Press, 2008. Available at: < http:/ / papers. ssrn.com/sol3/papers.cfm?abstract_id=1003387>.

SHUE, Henry. The interdependence of rights: the right to food. Leida: Martinus Nijhoff Publishers, 1984. 
SIMONS, Penelope; MACKLIN Audrey. The governance gap: extractive industries, human rights, and the home state advantage. London: Routledge, 2014.

SOVEREIGN wealth fund rankings: SWFI: Sovereign Wealth Fund Institute. Available at: <https://www. swfinstitute.org/sovereign-wealth-fund-rankings/>.

STATE-OWNED ASSETS SUPERVISION AND ADMINISTRATION COUNCIL. Guidelines to the State-owned enterprises directly under the central government on fulfilling corporate social responsibilities. Available at: <http:// en.sasac.gov.cn/n1408035/c1477196/content.html>.

TONINELLI, Pierangelo Maria. The rise and fall of stateowned enterprise in the western world. Cambridge: Cambridge University Press, 2000.

UN WORKING GROUP ON BUSINESS AND HUMAN RIGHTS. The state as an economic actor and buman rights: further unpacking practical implications of international business and human rights principles for the "state-business nexus".

UNITED NATIONS. Draft UN code of conduct on transnational corporations: [1983 Version]. Available at: <investmentpolicyhub.unctad.org/Download/TreatyFile/2891>.

UNITED NATIONS. Economic on Economic, Social and Cultural Rights. General comment n. 24 (2017) on State obligations under the International Covenant on Economic, Social and Cultural Rights in the context of business activities, 2017.

UNITED NATIONS. General Assembly. Human Right Council. Leading by example: the state, state-owned enterprises and human rights: report of the working group on the issue of human rights and transnational corporations and other business enterprises. 2016. (A/ $\mathrm{HRC} / 32 / 45)$

UNITED NATIONS. General Comment n. 31 (2004) on Art 2 of the ICCPR: the Nature of the general legal obligation imposed on states parties to the covenant, 2004.

UNITED NATIONS. Human Rights Concil. Promotion and protection of all human rights, civil, political, economic, social and cultural rights, including the right to development: report of the working group on the issue of human rights and transnational corporations and other business enterprises. 2016. (A/HRC/32/45)

UNITED NATIONS. Human Rights Concil. Promotion and protection of all human rights, civil, political, economic, social and cultural rights, including the right to development: report of the working group on the issue of human rights and transnational corporations and other business enterprises on its mission to Brazil. 2016. (A/HRC/32/45/ Add.1)

UNITED NATIONS. Human Rights Concil. Promotion and protection of all buman rights, civil, political, economic, social and cultural rights, including the right to development: report of the working group on the issue of human rights and transnational corporations and other business enterprises on its mission to Mexico. 2017. (A/HRC/35/32/ Add.2)

UNITED NATIONS. Human Rights Concil. Promotion andprotection of all human rights, civil, political, economic, social and cultural rights, including the right to development: report of the working group on the issue of human rights and transnational corporations and other business enterprises on its visit to the Republic of Korea. 2017. (A/ HRC/35/32/Add.1)

UNITED NATIONS. Human Rights Council. Resolution 17/4 buman rights and transnational corporations and other business enterprises. 2011. (A/HRC/RES/17/4)

UNITED NATIONS. Human Rights Council. Promotion of all human rights, civil, political, economic, social and cultural rights, including the right to development: business and human rights: towards operationalizing the "protect, respect and remedy" framework: report of the special representative of the Secretary-General on the issue of human rights and transnational corporations and other business enterprises. 2009. (A/HRC/11/13)

UNITED NATIONS. International Law Commission. Draft articles on responsibility of states for internationally wrongful acts, with commentaries. 2008. Available at: <http://legal.un.org/ilc/texts/instruments/english/ commentaries/9_6_2001.pdf >.

UNITED NATIONS. Office of the High Commissioner for Human Rights. CESCR General Comment 3, the nature of States parties obligations: art. 2, par.1 of the ICESCR. 14 dez. 1990.

UNITED NATIONS. Office of the United Nations High Commissioner for Human Rights. Principles and guidelines for a human rights approach to poverty reduction strategies. 2012. (HR/PUB/06/12)

UNITED NATIONS. The corporate responsibility to respect human rights: an interpretative guide. 2002. (HR/ PUB/12/02) 
UNITED NATIONS. World investment report 2014: investing in the SDGs: an action plan. 2014

UNITED NATIONS. World investment report 2017: investment and the digital economy. 2017.

UNIVERSITY OF MINNESOTA. Human Rights Library. Norms on the responsibilities of transnational corporations and other business enterprises with regard to buman rights: E/CN.4/Sub.2/2003/12/Rev.2. 2003.

VELÀSQUEZ Rodríguez v Honduras: Judgment of july 29, 1988, Inter-AmCtHR (Ser C) N. 4 (1988). University of Minnesota, 1988.

ZERK, Jennifer A. Multinationals and corporate social responsibility: limitations and opportunities in international law. First paperback edition. Cambridge: Cambridge University Press, 2011.

Acknowledgement

This paper was developed out of conversations with Assoc. Prof. Justine Nolan and Dr. Caroline Van Ham. I am extremely grateful to them for their guidance, support and encouragement which helped me develop this article to fruition. 
Para publicar na Revista de Direito Internacional, acesse o endereço eletrônico www.rdi.uniceub.br ou www.brazilianjournal.org.

Observe as normas de publicação, para facilitar e agilizar o trabalho de edição. 